\title{
Growth Kinetics and Distribution of Trace Elements in Precious Corals
}

\author{
Daniel Vielzeuf ${ }^{1 *}$, Alexander C. Gagnon ${ }^{2}$, Angèle Ricolleau' ${ }^{1}$, Jean-Luc Devidal ${ }^{3}$, \\ Catherine Balme-Heuze ${ }^{4}$, Nassima Yahiaoui', Claire Fonquernie'2, Jonathan Perrin ${ }^{1,5}$, \\ Joaquim Garrabou ${ }^{6}$, Jean-Marc Montel ${ }^{7}$ and Nicole Floquet ${ }^{1}$
}

${ }^{1}$ Aix Marseille Université, CNRS, Centre Interdisciplinaire de Nanoscience de Marseille, UMR 7325, Marseille, France, ${ }^{2}$ School of Oceanography, University of Washington, Seattle, WA, United States, ${ }^{3}$ Laboratoire Magmas et Volcans, Université Blaise Pascal - CNRS - IRD, OPGC, Aubière, France, ${ }^{4}$ Corallium, La Ciotat, France, ${ }^{5}$ Synchrotron Soleil, L'Orme des Merisiers, Saint-Aubin, France, ${ }^{6}$ Institut de Ciencies del Mar - CSIC, Barcelona, Spain, ${ }^{7}$ Université de Lorraine, CREGU, CNRS, Ecole Nationale Supérieure de Géologie, Laboratoire Géoressources, Vandœuvre-lès-Nancy, France

OPEN ACCESS

Edited by:

Karim Benzerara,

Centre National de la Recherche Scientifique (CNRS), France

Reviewed by: Rinat Gabitov, Mississippi State University, United States

Thomas M. DeCarlo, University of Western Australia, Australia

Hans Uwe Dahms, Kaohsiung Medical University, Taiwan

${ }^{*}$ Correspondence: Daniel Vielzeuf vielzeuf@cinam.univ-mrs.fr

Specialty section: This article was submitted to Biogeoscience,

a section of the journal Frontiers in Earth Science

Received: 11 July 2018 Accepted: 28 September 2018 Published: 18 October 2018

Citation: Vielzeuf D, Gagnon AC, Ricolleau A, Devidal J-L, Balme-Heuze C, Yahiaoui N, Fonquernie C, Perrin J,

Garrabou J, Montel J-M and Floquet N (2018) Growth Kinetics and Distribution of Trace Elements in Precious Corals.

Front. Earth Sci. 6:167. doi: 10.3389/feart.2018.00167
The concentration and spatial distribution of major $(\mathrm{Ca}, \mathrm{Mg})$ and trace elements $(\mathrm{Na}$, $\mathrm{Sr}, \mathrm{S}, \mathrm{Li}, \mathrm{Ba}, \mathrm{Pb}$, and $\mathrm{U}$ ) in different Corallium skeletons (C. rubrum, C. japonicum, C. elatius, C. konojoi) have been studied by electron microprobe (EMP) and laser ablation inductively coupled plasma mass spectrometry (LA-ICPMS). EMP data show positive $\mathrm{Na}-\mathrm{Mg}$ and negative $\mathrm{Na}-\mathrm{S}$ and $\mathrm{Mg}-\mathrm{S}$ correlations in all skeletons. LA-ICPMS data display additional Sr-Mg, Li-Mg, and U-Mg positive correlations. Medullar zones in the skeletons, corresponding to fast growing zones, are systematically richer in $\mathrm{Mg}, \mathrm{Na}$, $\mathrm{Sr}, \mathrm{Li}$, and $\mathrm{U}$ and poorer in $\mathrm{S}$ than the surrounding slow growing zones. These spatial distributions are mostly interpreted in terms of growth kinetics combined with steric effects influencing the incorporation of impurities in biogenic calcites. This interpretation is in agreement with available experimental data on kinetic effects on the incorporation of elements in calcite. At a different scale, annual growth rings in annular slow growing zones show oscillations in $\mathrm{Mg}, \mathrm{Na}, \mathrm{Sr}$, and $\mathrm{S}$. These chemical oscillations probably result from growth rate variations: fast growth would produce rings enriched in $\mathrm{Mg}$, Sr, and $\mathrm{Na}$, while slow growth would produce rings enriched in $\mathrm{Ca}, \mathrm{S}$ and organic matter. From previous studies in C. rubrum, the Mg-rich rings would develop during the spring to fall period while the S-rich rings would form immediately after (late fall and winter). Analytical traverses performed in annular zones of different Corallium skeletons indicate that $\mathrm{Mg}$, $\mathrm{Na}, \mathrm{Sr}, \mathrm{Li}$, and $\mathrm{U}$ decrease from core to rim. This observation indicates that radial growth rate decreases as the colony gets older. Contrary to $\mathrm{Mg}, \mathrm{Na}, \mathrm{Sr}, \mathrm{Li}, \mathrm{S}$, and $\mathrm{U}$, barium and lead concentrations are identical in medullar and annular zones and appear independent of growth kinetics. Thus, concentrations in Corallium skeletons could provide indications on $\mathrm{Ba}$ and $\mathrm{Pb}$ contents in the oceans. Barium and lead concentrations are higher in Mediterranean than in Pacific precious corals, these two elements can be used to discriminate $C$. rubrum from $C$. japonicum, and contribute enforcing regulations on the trade of precious corals.

Keywords: Corallium skeleton, chemical composition, annular zone, medullar zone, growth ring 


\section{INTRODUCTION}

Chemical contents of major, minor, and trace elements vary and are spatially arranged in Corallium skeletons (Weinbauer et al., 2000; Vielzeuf et al., 2008, 2013; Hasegawa et al., 2012; Nguyen et al., 2014; Tamenori et al., 2014). An important point is to determine whether these variations are due to environmental parameters, biological or mineralogical influences, or combinations of factors. The impact of environmental parameters on chemical contents of Corallium skeletons is debated. Weinbauer et al. (2000) considered that the concentrations of magnesium in Corallium rubrum is an indicator of sea water temperature. A positive correlation of $\mathrm{Mg} / \mathrm{Ca}$ with sea water temperature is also inferred by Yoshimura et al. (2011). Alternatively, Vielzeuf et al. (2013) showed that $\mathrm{Mg} / \mathrm{Ca}$ and $\mathrm{Sr} / \mathrm{Ca}$ ratios in C. rubrum collected at various locations and different depths $(8-73 \mathrm{~m})$, and thus different temperatures, cannot be used as proxies of sea water temperature. They also demonstrated that a single colony that grew in an area where the temperature was monitored for 30 years did not register the increase of sea water temperature of about $1^{\circ} \mathrm{C}$ through its $\mathrm{Mg}$ and $\mathrm{Sr}$ chemistry. These authors suggested that the $\mathrm{Mg}$ spatial distribution could be an indicator of growth rate variations on decadal time scales and that C. rubrum was an example of how growth dynamics affected biomineral chemistry. The hypothesis that elemental distributions depend on skeleton growth kinetics is difficult to test in situ on Corallium species with slow growth rates (Garrabou and Harmelin, 2002; Marschal et al., 2004; Vielzeuf et al., 2008, 2013; Hasegawa et al., 2012). An indirect route can be taken as Corallium skeletons systematically display a central core (or medullar zone) surrounded by an annular zone (Lacaze-Duthiers, 1864; Marschal et al., 2004; Vielzeuf et al., 2008; Perrin et al., 2015). The medullar zone is made of sclerites (small grains of $\mathrm{Mg}$-calcite developing in the living tissues around the hard skeleton) and sclerite aggregates embedded in a 'cement' consisting of fine layers of Mg-calcite. The annular zone is made of concentric layers of calcite crystallites with only rare sclerites (Figure 1). These contrasting features imply two different growth modes: (1) in the medullar zone, a "block and cement" mode takes place at the apex of a branch and is associated with a fast axial growth rate ( $\sim 2 \mathrm{~mm} /$ year); (2) in the annular zone, a layer-by-layer growth mode is associated with slow radial growth $(\sim 0.2 \mathrm{~mm} /$ year $)$ (Allemand, 1993; Garrabou and Harmelin, 2002; Marschal et al., 2004; Debreuil et al., 2012; Perrin et al., 2015). When necessary, medullar fast growing zones and annular slow growing zones will be abbreviated as MFGZ and ASGZ, respectively. These two contrasting zones provide an opportunity to determine whether growth rates impact the concentration of major and trace elements in biogenic calcite. Implications on the origin of growth rings in the annular slow growing zones are also discussed.

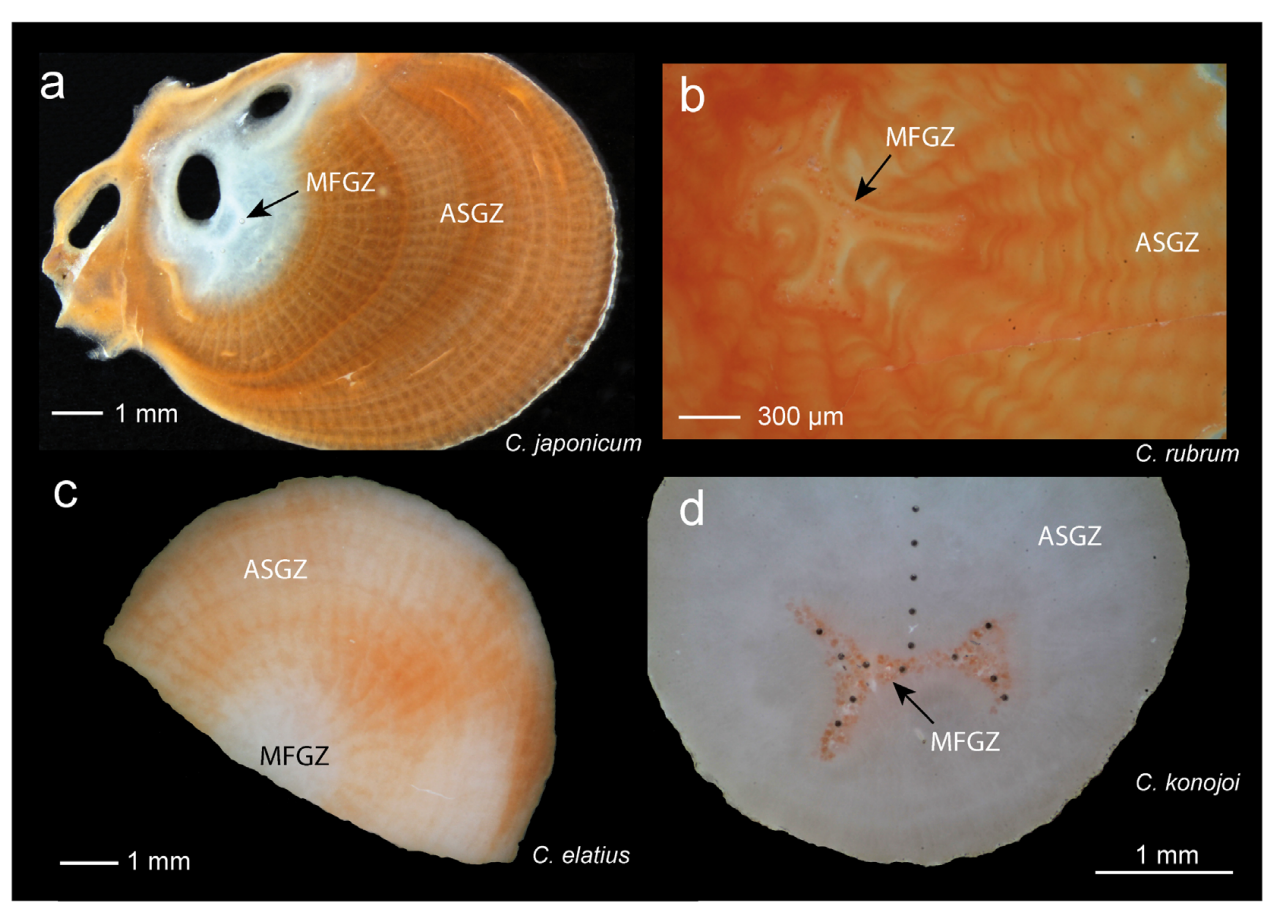

FIGURE 1 | Sections of Corallium skeletons under binocular magnifier. (a) C. japonicum. The medullar zone is located inside the white domain (black arrow), but does not coincide with it. The off-centered annular zone is white around the medullar zone, then red. (b) C. rubrum. Enlargement showing the medullar zone with its characteristic morphology. Sclerites appear as dark units inside the medullar zone. The annular zone with concentric annual layers surrounds the medullar zone. (c) Perpendicular section of $C$. elatius. The medullar zone located in the inner white zone is not readily identifiable. (d) Section of $C$. konojoi. The medullar zone can be identified because of the red color of the sclerites. The dark dots correspond to LA-ICPMS spots. MFGZ, medullar fast growing zone; ASGZ, annular slow growing zone. 


\section{MATERIALS AND METHODS}

\section{Materials}

Colonies of C. rubrum were collected along the rocky coast of the Mediterranean Sea between Marseille and Cassis (France). Colonies of $C$. elatius and C. japonicum come from various locations in Tosa Bay (Shikoku, Kochi, Japan). Other samples of C. elatius and some samples of C. japonicum of unknown origin were obtained from a jeweller's private collection. Two other samples from this collection with uncertain taxonomic identification (Midway C. sp. and Deep sea C. sp.), were studied. Geographic locations and sampling dates are given as Supplementary Material (SM) in SM1 Table 1. For the analyses, the samples were cut perpendicular (more rarely parallel) to the main axis of the branch, with or without removal of the dried organic tissues, mounted and polished in epoxy. In some colonies, sclerites were extracted from the organic tissues by immersion of the specimen in sodium hypochlorite $(5 \%)$ for about $2 \mathrm{~h}$, rinsed a few times with demineralized water then ethanol, and dried at room temperature. Portions of skeletons and sclerites were ground in ethanol for bulk analyses by ICP-OES and ICPMS. Note that the high-magnesium calcite corals used in this study are mineralogically, compositionally, physiologically, and genetically different from the aragonitic reef-forming (scleractinian) corals, and geochemical trends are not expected to be similar between these two orders of Anthozoa.

\section{Analytical and Preparation Methods}

Techniques with complementary capabilities were used to obtain comprehensive chemical information on Corallium skeletons. Electron microprobe (EMP) provides good spatial resolution and allows accurate surface mapping of $\mathrm{Ca}, \mathrm{Mg}, \mathrm{S}$, and $\mathrm{Na}$. Laser ablation inductively coupled plasma mass spectrometry (LA-ICPMS) has better sensitivity and precision than EMP for minor and trace elements (like $\mathrm{Sr}, \mathrm{Ba}, \mathrm{Li}, \mathrm{B}, \mathrm{U}$ ), but its spatial resolution is not as good (spots of $50 \mu \mathrm{m}$ instead of $2-5 \mu \mathrm{m}$ ). Due to their sizes and shapes, sclerites are difficult to analyze in situ; thus, bulk analyses of C. rubrum skeletons and sclerites were obtained by inductively coupled plasma - optical emission spectroscopy (ICP-OES) and inductively coupled plasma mass spectrometry (ICPMS). Finally, hydrogen analyses were obtained with an organic element analyzer.

\section{Electron Microprobe (EMP)}

Electron microprobe chemical images of $\mathrm{Ca}, \mathrm{Mg}, \mathrm{Na}$, and $\mathrm{S}$ were obtained on thick polished samples embedded in epoxy, on a SX100 CAMECA electron microprobe [Laboratoire Magmas et Volcans (LMV), Clermont-Ferrand, France]. For image acquisition, the beam current, beam diameter, counting times,

TABLE 1 | Electron microprobe analyses of Corallium skeletons.

\begin{tabular}{|c|c|c|c|c|c|c|c|c|c|c|c|}
\hline & $n$ & & $\begin{array}{c}\mathrm{Ca} \\
\mu \mathrm{g} / \mathrm{g}\end{array}$ & $\begin{array}{c}M g \\
\mu g / g\end{array}$ & $\begin{array}{c}\mathrm{Sr} \\
\mu \mathrm{g} / \mathrm{g}\end{array}$ & $\begin{array}{c}\mathrm{Na} \\
\mu \mathrm{g} / \mathrm{g}\end{array}$ & $\begin{array}{c}S \\
\mu \mathrm{g} / \mathrm{g}\end{array}$ & $\begin{array}{c}\mathrm{Cl} \\
\mu \mathrm{g} / \mathrm{g}\end{array}$ & $\begin{array}{c}\text { C } \\
\mu g / g\end{array}$ & $\begin{array}{c}0 \\
\mu g / g\end{array}$ & $\frac{\mathrm{Mg} / \mathrm{Mg}+\mathrm{Ca}}{\text { At. } \mathrm{Nb} .}$ \\
\hline & & $S D$ & 2125 & 592 & 216 & 248 & 129 & & 738 & 1226 & 0.3 \\
\hline \multirow[t]{2}{*}{ C. thrinax } & 10 & $x$ & 342281 & 29118 & 2683 & 3327 & 2880 & & 125370 & 494342 & 12.3 \\
\hline & & $S D$ & 5795 & 1685 & 200 & 496 & 167 & & 2039 & 3247 & 0.7 \\
\hline \multirow[t]{2}{*}{ C. niobe } & 10 & $x$ & 350333 & 24216 & 2375 & 3440 & 3077 & & 124464 & 492096 & 10.2 \\
\hline & & $S D$ & 1986 & 478 & 174 & 381 & 114 & & 778 & 1286 & 0.2 \\
\hline \multirow[t]{2}{*}{ C. konojoi } & 11 & $x$ & 347889 & 27156 & 2523 & 3077 & 3180 & & 124096 & 492079 & 11.4 \\
\hline & & $S D$ & 2542 & 930 & 202 & 395 & 259 & & 696 & 1126 & 0.4 \\
\hline Deep Sea (C. sp.) & 11 & $x$ & 353402 & 22951 & 2479 & 3156 & 2988 & & 123984 & 491040 & 9.7 \\
\hline C. japonicum ASGZ & & $S D$ & 1616 & 407 & 280 & 226 & 103 & & 609 & 968 & 0.2 \\
\hline \multirow[t]{2}{*}{ C. elatius MFGZ } & 14 & $x$ & 350027 & 24577 & 2588 & 3284 & 3330 & & 123815 & 492379 & 10.4 \\
\hline & & $S D$ & 3922 & 1799 & 305 & 400 & 356 & & 919 & 1535 & 0.8 \\
\hline \multirow[t]{2}{*}{ C. elatius ASGZ } & 30 & $x$ & 352833 & 22770 & 2377 & 2753 & 3641 & & 123613 & 492014 & 9.6 \\
\hline & & $S D$ & 1868 & 931 & 289 & 370 & 246 & & 583 & 922 & 0.4 \\
\hline \multirow[t]{2}{*}{ C. rubrum (Medes 2014) MFGZ } & 10 & $x$ & 344079 & 28063 & 2715 & 3339 & 3089 & 265 & 124960 & 493491 & 11.8 \\
\hline & & $S D$ & 2367 & 905 & 343 & 546 & 171 & 65 & 795 & 1254 & 0.4 \\
\hline \multirow[t]{2}{*}{ C. rubrum (Medes 2014) ASGZ } & 30 & $x$ & 349034 & 26026 & 2603 & 2765 & 3504 & 156 & 124040 & 491872 & 10.9 \\
\hline & & $S D$ & 2267 & 1272 & 348 & 425 & 283 & 56 & 586 & 911 & 0.5 \\
\hline
\end{tabular}

MFGZ, medullar fast growing zone; ASGZ, annular slow growing zone; $n$, number of analyses; $S D, 1 \sigma$ standard deviation. Values of $C$ and $O$ calculated by stoichiometry. 
and step interval varied in the range 10-50 nA, 1-2 $\mu \mathrm{m}, 30-50 \mathrm{~ms}$ per pixel, 1-5 $\mu \mathrm{m}$, respectively, with an acceleration voltage of $15 \mathrm{kV}$. In general, four images ( $\mathrm{Ca}, \mathrm{Mg}, \mathrm{Na}$, and $\mathrm{S}$ ) were acquired simultaneously during sessions that lasted $\sim 8 \mathrm{~h}$. All samples were coated with a $\sim 20 \mathrm{~nm}$ thick carbon layer. Quantitative analyses (spot analyses, usually along analytical traverses) of Ca, $\mathrm{Mg}, \mathrm{Na}, \mathrm{Sr}$, and $\mathrm{S}$ were obtained on nine different Corallium species. In addition, $\mathrm{Cl}$ was analyzed in C. rubrum. Typical EMP internal instrumental $(1 \sigma)$ errors on analyzed corals are 2,900, 830, 620, 840, 250, and $110 \mu \mathrm{g} / \mathrm{g}$, for $\mathrm{Ca}, \mathrm{Mg}, \mathrm{Na}, \mathrm{Sr}$, $\mathrm{S}$, and $\mathrm{Cl}$, respectively. Special attention was paid to analytical conditions as sulfur can be lost during analysis, in particular under focused beam. The optimal conditions were $20 \mathrm{nA}, 20 \mu \mathrm{m}$, $20 \mathrm{~s}$ [for all elements except $\mathrm{Na}(10 \mathrm{~s})$ ] for the beam current, beam diameter, and counting time, respectively, with an acceleration voltage of $15 \mathrm{kV}$. Conditions to analyze simultaneously $\mathrm{Sr}$ and $\mathrm{S}$ by EMP are antagonistic as Sr requires long counting times and focused beam while $S$ needs the opposite. We decided to optimize sulfur analytical conditions because $\mathrm{Sr}$ concentrations can be also measured by LA-ICPMS. Concerning sodium, similar concentrations and distribution patterns were observed in samples treated and untreated by sodium hypochlorite. This absence of effect is due to the high density of Corallium skeletons and removal of altered surfaces by polishing. The compositions in weight percent oxide were measured by EMP as $\mathrm{CaO}, \mathrm{Na}_{2} \mathrm{O}, \mathrm{SrO}, \mathrm{SO}_{3}, \mathrm{MgO}$. Natural calcite, albite, celestine, periclase, and scapolite (for $\mathrm{Cl}$ ) were used as standards. Matrix effects were corrected using the phi-rho-z correction available on Peak Sight $\left(\right.$ software from CAMECA $^{\text {TM }}$. Since C and $\mathrm{O}$ are not independently measured, $\mathrm{CO}_{2}$ was calculated by stoichiometry from the concentrations of $\mathrm{CaO}, \mathrm{MgO}, \mathrm{SrO}, \mathrm{Na}_{2} \mathrm{O}$ considering that $\mathrm{Ca}, \mathrm{Mg}, \mathrm{Sr}$, and $\mathrm{Na}$ combine into carbonate and sulfate, according to the structural formula $\left(\mathrm{Ca}_{\mathrm{w}} \mathrm{Mg}_{\mathrm{x}} \mathrm{Sr}_{\mathrm{y}} \mathrm{Na}_{\mathrm{z}}\right)_{\mathrm{A}}$ $\left.\left[\left(\mathrm{CO}_{3}\right)_{\mathrm{u}}\left(\mathrm{SO}_{4}\right)_{\mathrm{v}}\right)\right]_{\mathrm{A}}$, with $\mathrm{w}+\mathrm{x}+\mathrm{y}+0.5 \mathrm{z}=\mathrm{u}+\mathrm{v}=\mathrm{A}$. This way, $\mathrm{C}$ and $\mathrm{O}$ wt $\%$ contents can be determined, together with analysis totals. Totals in the range $99 \pm 3 \mathrm{wt} \%$ are considered as an indication of a good analysis. Throughout this article, elemental concentrations are given in $\mu \mathrm{g} / \mathrm{g}$ (or ppm), elemental ratios (e.g., $\mathrm{Mg} / \mathrm{Ca}$ ) in $\mathrm{mmol} / \mathrm{mol}$, and the proportion of $\mathrm{MgCO}_{3}$ in calcite in mol\%.

\section{Laser Ablation Inductively Coupled Plasma Mass Spectrometry (LA-ICPMS)}

Trace element analyses were obtained at LMV (Clermont-Ferrand, France) on an Agilent 7500 cs ICPMS coupled to a $193 \mathrm{~nm}$ Excimer Resonetics M-50E laser ablation system with maximum output energy of $6 \mathrm{~mJ}$. Analyses were made with a laser pulse frequency of $2 \mathrm{~Hz}$ and a constant beam diameter of $40 \mu \mathrm{m}$. The ablated material was carried by helium $(0.7 \mathrm{~L} / \mathrm{min})$ and then mixed with nitrogen and argon in front of the ICP. The following isotopes were collected: ${ }^{7} \mathrm{Li},{ }^{23} \mathrm{Na}$, ${ }^{24} \mathrm{Mg},{ }^{31} \mathrm{P},{ }^{66} \mathrm{Zn},{ }^{88} \mathrm{Sr},{ }^{137} \mathrm{Ba},{ }^{208} \mathrm{~Pb},{ }^{238} \mathrm{U}$, with integration times varying between 30 and $200 \mathrm{~ms}$ depending on the element and the session. Typical minimum detection limits are 0.04, 0.3, 0.2, $4.5,0.2,0.02,0.12,0.02$, and $0.01 \mu \mathrm{g} / \mathrm{g}$ for $\mathrm{Li}, \mathrm{Na}, \mathrm{Mg}, \mathrm{P}, \mathrm{Zn}, \mathrm{Sr}$, $\mathrm{Ba}, \mathrm{Pb}$, and $\mathrm{U}$, respectively. Internal instrumental $(1 \sigma)$ errors are typically in the range of $0.1,120,1040,20,0.10,80,0.2,0.01$, and $0.01 \mu \mathrm{g} / \mathrm{g}$, for $\mathrm{Li}, \mathrm{Na}, \mathrm{Mg}, \mathrm{P}, \mathrm{Zn}, \mathrm{Sr}, \mathrm{Ba}, \mathrm{Pb}$, and $\mathrm{U}$, respectively.
The mean calcium abundance measured by EMP for each coral sample was used as internal standard. A typical signal acquisition consisted in collecting a background signal for $30 \mathrm{~s}$ followed by laser firing for $70 \mathrm{~s}$. Trace-element reductions were done with the Glitter software (Van Achterbergh et al., 2001). The long firing time (70 s) allowed checking (1) if the signal was stable during the measure (flat plateau) and (2) if any voids or inclusions were encountered during firing. Only flat plateau portions were processed, and initial spikes or signals associated with surface contamination were systematically discarded. The NIST 610 glass was used as an external standard (Shaheen et al., 2008). The glasses NIST 612 and BCR-2G (Gao et al., 2002) were also analyzed to check the accuracy and precision of the analyses.

\section{Inductively Coupled Plasma - Optical Emission Spectroscopy and Inductively Coupled Plasma Mass Spectrometry (ICP-OES and ICPMS)}

Bulk samples of sclerites, branch tips, and branch bases were extracted from two colonies of C. rubrum collected at the same location in the Calanques of Marseille, at two different periods of the year (October and April). Major and trace element analyses of the six powdered samples were obtained on a Thermo ICP-OES Icap 6500 and Thermo IcapQ, respectively, at Service d'Analyse des Roches et des Minéraux (SARM), Centre de Recherches Pétrologiques et Géochimiques (CRPG), Nancy, France. $200 \mathrm{mg}$ of material were used for each analysis. Procedures and instrumental errors are given in Carignan et al. (2001).

Thirty-four samples of skeletons from nine different C. rubrum colonies collected in the Calanques area (Marseille, France), and 14 sclerite batches extracted from colonies coming from various places in the Mediterranean were analyzed by isotope dilution (ID) - ICPMS at the Division of Geological and Planetary Sciences at Caltech, Pasadena, CA, United States. The analytical conditions to determine $\mathrm{Mg} / \mathrm{Ca}$ and $\mathrm{Sr} / \mathrm{Ca}$ ratios are given in Vielzeuf et al. (2013). The long term external reproducibility of coral analysis using ID-ICPMS, as determined by the $2 \sigma$ standard deviation of repeat measurements of two different dissolved coral consistency standards, is better than $\pm 0.003 \mathrm{mmol} / \mathrm{mol}(\mathrm{Sr} / \mathrm{Ca})$ and $\pm 0.5 \mathrm{mmol} / \mathrm{mol}(\mathrm{Mg} / \mathrm{Ca})$.

\section{Organic Element Analyzer}

$\mathrm{C}, \mathrm{H}, \mathrm{N}$, and $\mathrm{S}$ contents of skeletons and sclerites were obtained at LMV (Clermont-Ferrand, France). Three analytical standards and reference materials were used in the process: BBOT $\left(\mathrm{C}_{26} \mathrm{H}_{26} \mathrm{~N}_{2} \mathrm{O}_{2} \mathrm{~S}\right)$, ascorbic acid $\left(\mathrm{C}_{6} \mathrm{H}_{8} \mathrm{O}_{6}\right)$, and a soil reference (homogeneous batch of soil from Thermo Scientific) for $\mathrm{C}, \mathrm{N}$, and $\mathrm{S}$. About $1 \mathrm{mg}$ of sample, analytical standard or reference material was weighed in a tin capsule on a XP6 microbalance (Mettler Toledo, Greifensee, Switzerland) with a $1 \mu \mathrm{g}$ resolution. Similar amounts of $\mathrm{V}_{2} \mathrm{O}_{5}$ were added to the sample to optimize the combustion. Analyses were carried out in a Flash 2000 CHNS-O organic elemental analyzer from Thermo Fisher Scientific Inc., equipped with a MAS 200R autosampler. During the analyses, the following parameters were used: 2.4 bar helium with a $140 \mathrm{~mL} / \mathrm{min}$ flow rate of carrier gas and a $120 \mathrm{~mL} / \mathrm{min}$ flow rate of reference gas, 2.2 bar oxygen with a flow rate of $90 \mathrm{~mL} / \mathrm{min}$, and an injection end time (duration of $\mathrm{O}_{2}$ 
injection) of $11 \mathrm{~s}$. Accuracies of the measurements are better than $1 \%$ relative for $\mathrm{C}$ (i.e., $\pm 1,200 \mu \mathrm{g} / \mathrm{g}$ ), and $10 \%$ relative for $\mathrm{H}$ and S (i.e., $\pm 200 \mu \mathrm{g} / \mathrm{g}$ ).

\section{RESULTS}

\section{Concentrations of Elements and Correlations}

\section{$\mathrm{Ca}, \mathrm{Mg}, \mathrm{Sr}, \mathrm{Na}$, and $\mathrm{S}$ Measured by EMP}

Calcium, magnesium, strontium, sodium, and sulfur concentrations of nine Corallium species are given in Table $\mathbf{1}$. The magnesium content is rather constant among the different species $\sim 11 \pm 1 \mathrm{~mol} \% \mathrm{MgCO}_{3}$, except for the Midway $\mathrm{C}$. sp. sample that has a lower $\mathrm{Mg}$ content $\left(7.7 \mathrm{~mol} \% \mathrm{MgCO}_{3}\right.$ ). The Sr content does not vary much either, between 2,200 and $2,700 \mu \mathrm{g} / \mathrm{g}$. As already noted for C. rubrum (Vielzeuf et al., 2013), the $\mathrm{Na}$ and $\mathrm{S}$ contents are relatively high, in the range 3,000-3,400 and 2,900-3,600 $\mu \mathrm{g} / \mathrm{g}$ for $\mathrm{Na}$ and $\mathrm{S}$, respectively. The chlorine contents measured in C. rubrum vary between 20 and $370 \mu \mathrm{g} / \mathrm{g}$.

Correlations that may exist between elements are critical to understand the crystallo-chemistry of biogenic $\mathrm{Mg}$ calcites. A negative correlation necessarily exists between $\mathrm{Ca}$ and $\mathrm{Mg}$ [because (1) the sum of cations is fixed in $\mathrm{Mg}$ calcite, and (2) $\mathrm{Ca}$ and $\mathrm{Mg}$ are the two predominant cations]; thus, the classic $\mathrm{Ca}-\mathrm{Mg}$ substitution does not need further discussion. Other correlations are more unexpected. In most Corallium species, a positive correlation is observed between $\mathrm{Na}$ and $\mathrm{Mg}$ (Figure 2A). The two exceptions (Midway C. sp. and C. niobe) are attributed to insufficient number of analyses and limited range of $\mathrm{Mg}$ contents. A similar $\mathrm{Na} / \mathrm{Mg}$ correlation has been recently described in deep sea calcitic octocorals (Rollion-Bard et al., 2017). For clarity, the data of $C$. elatius have been isolated (Figure 2D), the dots are moderately aligned with a correlation coefficient $\left(r^{2}\right)$ of 0.52 (Supplementary Material SM1 Table 3). A second correlation is observed between $\mathrm{Na}$ and $\mathrm{S}$ (Figure 2B). Indeed, if the cases of Midway C. sp. and C. niobe are ignored (same justification as above), all species display a negative correlation between $\mathrm{Na}$ and $\mathrm{S}$ ( $r^{2}$ between 0.3 and 0.7 - Supplementary Material SM1 Table 3). Figure 2E shows the same diagram with only two species: C. japonicum and C. elatius. As shown in Figures 2C,F, a negative correlation between $\mathrm{S}$ and $\mathrm{Mg}$ arises from the two previous ones (Na-Mg, and Na-S). In this case, all species, including Midway $\mathrm{C}$. sp. and C. niobe, display negative correlations between $\mathrm{S}$ and $\mathrm{Mg}$ ( $r^{2}$ between 0.1 and 0.8 - Supplementary Material SM1 Table 3). Finally, contrary to what will be observed later on LA-ICPMS data, no correlation is observed between $\mathrm{Sr}$ and $\mathrm{Mg}$ on EMP data. As discussed earlier, this lack of correlation is attributed to the relatively poor Sr precision under selected EMP analytical conditions.

\section{Trace Elements Concentrations Measured by LA-ICPMS}

$\mathrm{Na}$ concentrations determined by LA-ICPMS in C. rubrum, C. japonicum, C. elatius, and C. konojoi, (3,700, 3,800, 3,700, 3,900 $\mu \mathrm{g} / \mathrm{g}$, respectively - Supplementary Material SM1 Table 2) are higher than those determined by $\operatorname{EMP}(3,100,3,200,3,000$, 3,100) (Table 1). Differences are attributed to the instruments and possible Na losses during EMP analyses, but also to concentration variabilities, within a sample and from a sample to another. Concerning Sr, the concentrations obtained with the two instruments are similar within error and/or sample internal variation [LA-ICPMS: 2,700, 2,600, 2,800, 2,700 $\mu \mathrm{g} / \mathrm{g}$; EMP: 2,700, 2,500, 2,500, 2,500, for C. rubrum, C. japonicum, C. elatius, and C. konojoi, respectively]. Contrary to other elements that have almost similar concentrations in the different Corallium species, $\mathrm{Ba}$ and $\mathrm{Pb}$ concentrations are higher in C. rubrum than in C. japonicum, C. elatius, and C. konojoi (Ba: $8.2 \pm 1.1$ in C. rubrum vs. $6 \pm 0.8 \mu \mathrm{g} / \mathrm{g}$ in the three other species $\mathrm{Pb}: 0.48 \pm 0.19$ in C. rubrum vs. $0.14 \pm 0.02 \mu \mathrm{g} / \mathrm{g}$ in other species - Supplementary Material SM1 Table 2 and Figure 3). These differences will be interpreted later. During LA-ICPMS data acquisitions, contents of $\mathrm{P}, \mathrm{K}, \mathrm{Cr}, \mathrm{Mn}$, and $\mathrm{Zn}$ were often determined; the concentrations of these elements are given in Supplementary Material SM1 Table 2 but will not be discussed further here.

LA-ICPMS data point out positive correlations between $\mathrm{Sr}$ and $\mathrm{Mg}$ (Figure 4B) $\left(r^{2}\right.$ between 0.4 and 0.8 - Supplementary Material SM1 Table 3). Although the intercepts at $\mathrm{Mg}=0$ differ in the four species, from about 1,000 to $2,000 \mu \mathrm{g} / \mathrm{g}$ (Supplementary Material SM1 Table 3), the $\mathrm{Sr} / \mathrm{Mg}$ slopes are close (from 0.03 to 0.05 ). On another hand, Figure $4 \mathrm{~A}$ shows a positive correlation between $\mathrm{Na}$ and $\mathrm{Mg}$ for all species $\left(r^{2}\right.$ between 0.2 and 0.9 - Supplementary Material SM1 Table 3), confirming EMP observations (Figure 2A). Other correlations such as $\mathrm{Li}$ vs. $\mathrm{Mg}$, and $\mathrm{U}$ vs. $\mathrm{Mg}$ are displayed in Figure $\mathbf{5}$. C. elatius data have been isolated in Figures 5C,D. These figures indicate that data from each species have to be treated separately in order to establish (or not) elemental correlations as slight differences of concentration from a species to another (species dependence) may prevent global correlation. This observation is also valid for EMP correlations discussed earlier. Correlations coefficients $\left(r^{2}\right)$ of the data series displayed in Figures 2, 4, 5 are variable and sometimes low (Supplementary Material SM1 Table 3); however, the fact that similar trends are observed in all species adds credit to our conclusions.

\section{Hydrogen and Sulfur Measured by OEA}

Carbon, hydrogen, and sulfur have been analyzed by OEA in nine Corallium species (Table 2). Sulfur contents in the range 2,150-3,050 (mean value: 2,580 $\pm 330 \mu \mathrm{g} / \mathrm{g}$ ) are usually lower than those determined by EMP [range 2,880-3,640; mean value: $3,160 \pm 220 \mu \mathrm{g} / \mathrm{g}$ - excluding medullar zones (MFGZ) for reasons discussed below]. Due to the special attention paid on the analytical conditions of sulfur, the concentrations determined by EMP are considered more accurate than those determined by OEA on a bulk powder.

The measured concentrations of carbon vary from a species to another between 119,000 and $130,000 \mu \mathrm{g} / \mathrm{g}$. The theoretical values of carbon concentration in calcite $\left(\mathrm{CaCO}_{3}\right)$ and magnesite $\left(\mathrm{MgCO}_{3}\right)$ are 120,003 and $142,452 \mu \mathrm{g} / \mathrm{g}$, respectively. Thus, differences of $\mathrm{C}$ contents in Corallium species can be ascribed in part to differences in proportion of $\mathrm{MgCO}_{3}$ component, 

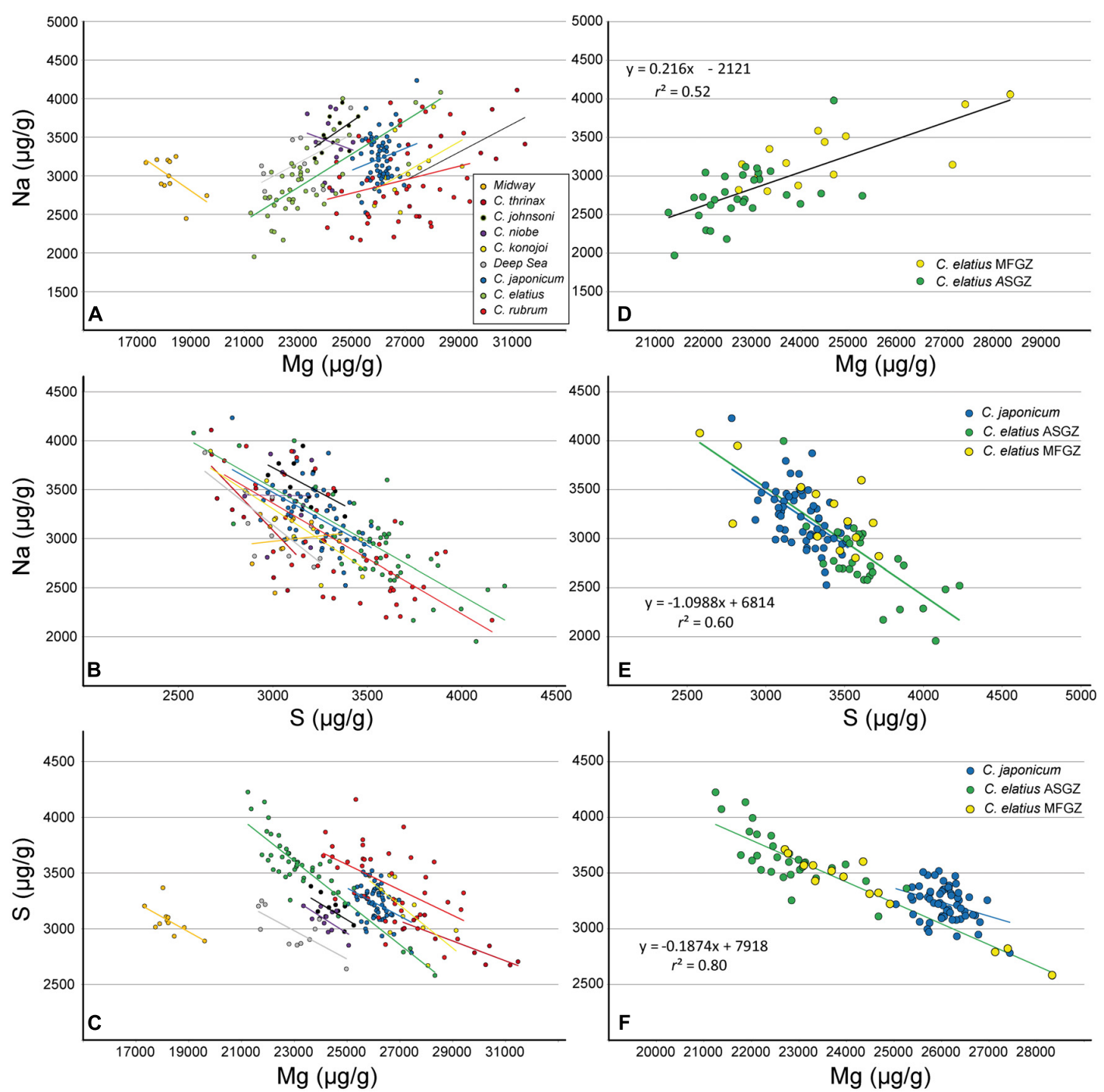

FIGURE 2 | Electron microprobe analyses of different Corallium skeletons [Midway (C. sp.), C. thrinax, C. johnsoni, C. niobe, C. konojoi, Deep sea (C. sp.), C. japonicum, C. elatius, C. rubrum]. (A-C) All data and linear adjustment for each species (equation parameters and correlation coefficients are supplied as Supplementary Material SM1 Table 3). (D-F) C. elatius and C. japonicum data extracted from (A-C). The equations and correlation coefficients correspond to C. elatius data (MFGZ and ASGZ combined). MFGZ, medullar fast growing zone; ASGZ, annular slow growing zone.

and from variations of organic matter (OM) content (see below). Carbon contents lower than $120,003 \mu \mathrm{g} / \mathrm{g}$ (the C content of inorganic calcite) may indicate the presence of sulfate substituting to carbonate ions as demonstrated in previous studies (Vielzeuf et al., 2013; Tamenori et al., 2014; Nguyen et al., 2014; Perrin et al., 2017).

Hydrogen contents in the skeletons can be related to the amount of $\mathrm{OM}$ in the biomineral if all $\mathrm{H}$ is contained in the $\mathrm{OM}$, and if the $\mathrm{H}$ content of the $\mathrm{OM}$ is known (Perrin et al., 2017). Concerning the first assumption, no evidence of hydrated $\mathrm{Mg}$ calcite in Corallium species has been found so far in Raman investigations (Merlin and Dele-Dubois, 1986). Concerning the OM hydrogen content, preliminary measurements of red coral tissues after decarbonation of the skeleton indicate $\mathrm{H}$ contents of about 76,000 $\mu \mathrm{g} / \mathrm{g}$ (7.6 wt\%).
In addition, hydrogen contents in organic constituents of a wide range of organisms are rather constant and close to 8-10 wt\% (Trask, 1937). A simple proportional calculation (skeleton hydrogen content/OM hydrogen content $\times 10^{6}$ ) gives the concentration of $\mathrm{OM}$ in the skeleton in $\mu \mathrm{g} / \mathrm{g}$. If the value of $76,000 \mu \mathrm{g} / \mathrm{g}$ is taken for the OM hydrogen content, then the OM concentrations in the Corallium species are close to 2 wt\%, except for Midway C. sp. that reaches $4.6 \mathrm{wt} \%$ (Table 2). Combining an error of $\pm 10 \%$ relative for the amount of $\mathrm{H}$ in the OM with an error of $\pm 10 \%$ relative for the amount of $\mathrm{H}$ in the skeleton translates into an error of $20 \%$ relative for the concentration of $\mathrm{OM}$ in the skeletons. It will be noted that the highest $\mathrm{C}$ contents coincide with the highest concentrations of OM, as expected due to the contribution of organic carbon. 
TABLE 2 | Carbon, hydrogen, and sulfur contents in Corallium species.

\begin{tabular}{lcccc}
\hline & C & H & S & \% OM \\
\hline Midway (C. sp.) & 130820 & 2510 & 2150 & $\mathbf{3 . 3}$ \\
C. thrinax & 119930 & 1830 & 2810 & $\mathbf{2 . 4}$ \\
C. johnsoni & 119950 & 2200 & 2760 & $\mathbf{2 . 9}$ \\
C. niobe & 121000 & 2290 & 2510 & $\mathbf{3 . 0}$ \\
C. konojoi Tk & 119910 & 1450 & 2320 & $\mathbf{1 . 9}$ \\
C. konojoi CBH & 119000 & 1350 & 2110 & $\mathbf{1 . 8}$ \\
Deep sea (C. sp.) & 131400 & 3470 & 3050 & $\mathbf{4 . 6}$ \\
C. japonicum & 120840 & 2090 & 2400 & $\mathbf{2 . 8}$ \\
C. elatius & 121180 & 1810 & 2890 & $\mathbf{2 . 4}$ \\
C. rubrum Sk & 119920 & 1960 & 2610 & $\mathbf{2 . 6}$ \\
C. rubrum Tip & 120150 & 2210 & 2570 & $\mathbf{2 . 9}$ \\
C. rubrum Scl & 121170 & 2318 & 2317 & $\mathbf{3 . 1}$ \\
\hline
\end{tabular}

Sk, skeleton; Tip, tip of a branch (representative of medullar zone); Scl, sclerites. The proportion of OM has been calculated considering that all hydrogen is in the $\mathrm{OM}$, and that the hydrogen OM content equals 7.6 wt\%.

\section{Comparison of Medullar-Fast and Annular-Slow Growing Zones EMP Data}

Although differences are small, C. japonicum, C. elatius, and C. rubrum mean compositions of medullar fast growing zones are systematically higher in $\mathrm{Mg}, \mathrm{Sr}, \mathrm{Na}, \mathrm{Cl}$, and lower in $\mathrm{Ca}$ and $S$ than annular slow growing zones (Table 1). These differences are verified on the chemical maps of $\mathrm{Mg}, \mathrm{Na}$, and $\mathrm{S}$ of C. rubrum, C. japonicum, C. elatius, and C. konojoi covering medullar and annular zones (Figure 6). In these maps, concentrations increase from black to white. Figures $\mathbf{6 a - i}$ show maps of transverse sections of C. elatius, C. rubrum, and C. japonicum branches while Figures $\mathbf{6 j - 1}$ display a sagittal (longitudinal) section of $C$. konojoi. The last figures show the complex 2-D shape of the medullar zone, a direct consequence of the rugged 3-D morphology of branch tips.

\section{LA-ICPMS Data}

LA-ICPMS measurements were made specifically on medullar and annular zones of C. rubrum, C. japonicum, C. elatius, and C. konojoi (Supplementary Material SM1 Table 2). These compositions are plotted in Figure 7 and confirm that medullar zones are richer in $\mathrm{Na}$ and $\mathrm{Mg}$ than annular zones $(\mathrm{Na}: \sim 4,140$ vs. $\sim 3,560, \mathrm{Mg}: \sim 31,000$ vs. $\sim 27,700 \mu \mathrm{g} / \mathrm{g}$, for medullar and annular zones, respectively). LA-ICPMS data also show that the medullar zones of the four species are enriched in $\mathrm{Li}$ (3.7 vs. $2.6 \mu \mathrm{g} / \mathrm{g}$ ), $\mathrm{U}$ (0.13 vs. $0.05 \mu \mathrm{g} / \mathrm{g}$ ), and $\mathrm{Sr}$ (2,780 vs. $2,610 \mu \mathrm{g} / \mathrm{g}$ - not shown in Figure 7), with respect to annular zones. The increase of $U$ content is particularly important as medullar zones contain two to five times more $U$ than the annular zone (Figure 7D), with a minimum of 0.05 and a maximum of $0.25 \mu \mathrm{g} / \mathrm{g}$ in C. elatius annular and medullar zones, respectively. A statistical analysis (Wilcoxon-Mann-Withney Test and principal component analysis) of both EMP and LA-ICPMS data confirms the difference of composition between annular and medullar zones (Supplementary Material SM2).

In annular zones, LA-ICPMS data were collected along traverses, from rim to core. Figure 8 shows an analytical traverse in a $C$. konojoi skeleton. It confirms that medullar and annular zones have different $\mathrm{Mg}, \mathrm{Na}, \mathrm{Li}, \mathrm{U}$, and to a smaller extent, Sr compositions. Most notably, Mg, $\mathrm{Na}, \mathrm{Sr}, \mathrm{Li}$, and $\mathrm{U}$ decrease progressively from core to rim in the annular zone. These patterns will be interpreted later.

\section{C. rubrum Skeleton and Sclerite Compositions Determined by ICP-OES, ICP-MS, and ID-ICP-MS}

Basal portions of skeleton branches, tips of branches and sclerites of two colonies of C. rubrum have been analyzed. The branch tip (that becomes later the medullar part) is made of sclerites embedded in Mg calcitic 'cement' (medullar cement). Note that the word 'cement' is used here in the structural sense of a material holding together separately built units (the sclerites). The basal portion of a branch is predominantly made of $\mathrm{Mg}$ calcite layers practically devoid of sclerites (annular zone) but it contains a small part of medullar zone (itself made of sclerites and medullar cement) (Allemand, 1993; Perrin et al., 2015). Results presented in Table 3 confirm that the tips (i.e., medullar zones) are richer in $\mathrm{Na}, \mathrm{Mg}$, and $\mathrm{U}$ than the basal branch (more representative of the annular zone). These results also confirm that the sclerites are richer in $\mathrm{Mg}$ than the skeleton (Weinbauer et al., 2000;

TABLE 3 | Chemical compositions of C. rubrum skeletons (Sk), tips and sclerites (Scl) determined by ICP-AES and ICP-MS (samples Sormiou Canceou and Falaise Voile).

\begin{tabular}{|c|c|c|c|c|c|c|c|c|c|c|c|c|c|}
\hline & $\mathrm{Na}$ & $\mathbf{M g}$ & $\mathrm{Ca}$ & $\mathrm{Cr}$ & $\mathrm{Ni}$ & $\mathbf{R b}$ & Sr & $\mathbf{Y}$ & Cd & $\mathrm{Nd}$ & Sn & $\mathrm{Ba}$ & La \\
\hline Sk & 3870 & 27300 & 347600 & < D.L. & $<$ D.L. & < D.L. & 2560 & 0.04 & 0.08 & < D.L. & < D.L. & 8.10 & 0.02 \\
\hline Tip & 3990 & 28500 & 345600 & 0.50 & 2.30 & 0.20 & 2500 & 0.04 & 0.11 & < D.L. & < D.L. & 8.90 & 0.03 \\
\hline \multirow[t]{2}{*}{ Scl } & 3520 & 30500 & 340600 & 1.00 & $<$ D.L. & < D.L. & 2320 & 0.15 & 0.28 & 0.04 & 0.33 & 8.30 & 0.06 \\
\hline & $\mathrm{Ce}$ & Pr & Sm & $\mathrm{Eu}$ & Gd & Dy & Ho & $\mathrm{Er}$ & $\mathrm{Yb}$ & $\mathrm{Hf}$ & Ta & $\mathrm{Pb}$ & $\mathbf{U}$ \\
\hline Sk & < D.L. & $<$ D.L. & < D.L. & < D.L. & $<$ D.L. & < D.L. & < D.L. & < D.L. & < D.L. & < D.L. & < D.L. & < D.L. & 0.05 \\
\hline Tip & 0.04 & 0.005 & < D.L. & < D.L. & $<$ D.L. & < D.L. & < D.L. & < D.L. & < D.L. & < D.L. & < D.L. & 0.75 & 0.08 \\
\hline Scl & 0.06 & 0.010 & 0.010 & 0.003 & 0.010 & 0.008 & 0.002 & 0.005 & 0.005 & 0.541 & 0.32 & 0.80 & 0.05 \\
\hline
\end{tabular}

Other elements below detection limit (D.L.): Al, As, Be, Bi, Co, Cs, Cu, Fe, Ga, Ge, In, Lu, Mn, Mo, Nb, P, Si, Sc, Sb, Th, Ti, Tm, V, W, Zr.

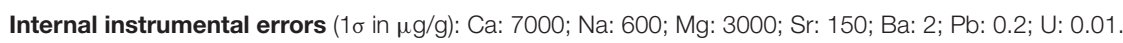




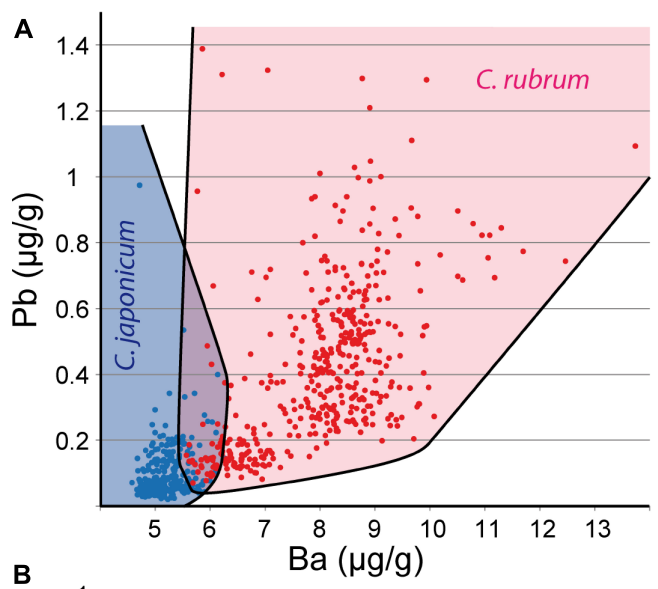

B

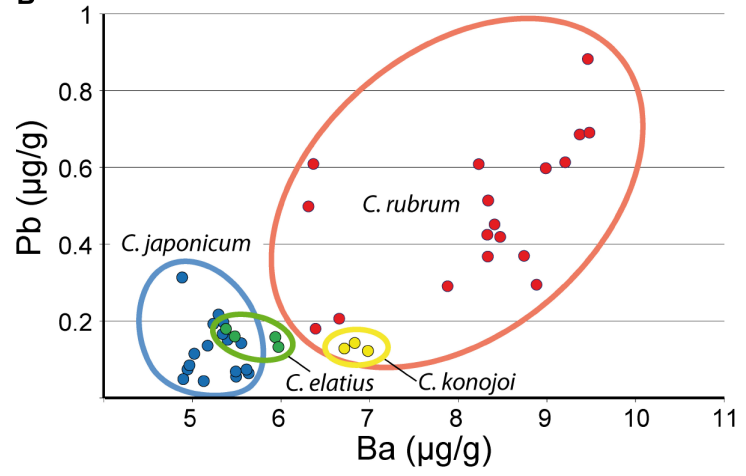

FIGURE 3 | Pb and Ba LA-ICPMS data. (A) Pb vs. Ba diagram showing the respective fields of $C$. rubrum and $C$. japonicum (all analyses). (B) $\mathrm{Pb}$ vs. Ba for C. rubrum, C. japonicum, C. elatius, and C. konojoi. Mean composition of analyzed colonies. Fields of $C$. elatius and $C$. konojoi are likely to expand with additional data.

Vielzeuf et al., 2013; Perrin et al., 2015). However, it is not yet known if the medullar 'cement' and annular zone (both made of $\mathrm{Mg}$ calcite crystallites) are similar or not in composition. If the medullar cement and annular zone had similar compositions, the tip should have an intermediate composition between annular zone and sclerites. Table 3 shows that even if it is the case for $\mathrm{Mg}$, it is not for $\mathrm{Na}, \mathrm{Ba}$, and U. From these observations, and in particular $U$ concentrations, it can be postulated that annular zones and medullar cements have different compositions. Thus, annular and medullar zone compositional differences discussed above on the basis of EMP and ICP-MS data cannot be simply ascribed to the presence of sclerites in the medullar zone. Finally, sclerites are poorer in $\mathrm{S}, \mathrm{Na}, \mathrm{Sr}$, and richer in rare earth elements (REEs) than the skeleton (Vielzeuf et al., 2013 for sulfur, and Table 3). In short, sclerites, tip 'cement' and annular zones have different compositions in C. rubrum.

$\mathrm{Mg} / \mathrm{Ca}$ and $\mathrm{Sr} / \mathrm{Ca}$ ratios obtained on C. rubrum skeletons and sclerites by ID-ICPMS, confirm that the sclerites are richer in $\mathrm{Mg}$ and slightly poorer in Sr than the skeletons. First indications of such differences in composition were provided by Weinbauer et al. (2000). Figure 8 shows that Mg and Sr are correlated in both the skeletons and the sclerites along two separated trends with identical slopes.
To summarize:

(1) EMP measurements of Corallium skeletons show positive correlations between $\mathrm{Na}$ and $\mathrm{Mg}$, and negative correlations between $\mathrm{Na}$ and $\mathrm{S}$, and $\mathrm{Mg}$ and $\mathrm{S}$.

(2) LA-ICPMS measurements confirm the positive $\mathrm{Na} / \mathrm{Mg}$ correlation in Corallium skeletons and also demonstrate $\mathrm{Sr} / \mathrm{Mg}, \mathrm{Li} / \mathrm{Mg}$, and $\mathrm{U} / \mathrm{Mg}$ positive correlations.

(3) EMP measurements indicate that medullar zones are systematically richer in $\mathrm{Mg}, \mathrm{Sr}, \mathrm{Na}$, (possibly $\mathrm{Cl}$ ) and poorer in $\mathrm{Ca}$ and $\mathrm{S}$ than annular zones. This conclusion is confirmed by LA-ICPMS data which also indicate that medullar zones are enriched in Li and $U$ compared to annular zones.

(4) Chemical traverses show that $\mathrm{Mg}, \mathrm{Na}, \mathrm{Sr}, \mathrm{Li}$, and $\mathrm{U}$ progressively decrease from core to rim in the annular zone of C. konojoi. Traverses in other precious corals show similar patterns.

(5) C. rubrum sclerites are richer in $\mathrm{Mg}$ and $\mathrm{REE}$, and poorer in $\mathrm{Sr}, \mathrm{Na}$, and $\mathrm{S}$, than the skeletons. Skeletons and sclerite display two separate positive $\mathrm{Sr} / \mathrm{Mg}$ correlations.

\section{DISCUSSION}

\section{Growth Kinetics and the Incorporation of Elements in Calcite}

The data presented above indicate that the concentrations of $\mathrm{Mg}$, $\mathrm{Na}, \mathrm{Sr}, \mathrm{Li}$, and $\mathrm{U}$ are higher in medullar fast growing zones than in the annular slow growing zone, and conversely for $\mathrm{Ca}$ and $\mathrm{S}$. Although not unique, a possible and parsimonious explanation for this situation is that the incorporation of these elements in Corallium biogenic calcites could be in part linked to growth kinetics. The idea that kinetics plays a role in the incorporation of impurities in crystals (and conversely) is probably as old as the concept of crystal growth itself. As a reminder, impurities in calcite include metal cations, anions (such as $\mathrm{SO}_{4}{ }^{2-}$ ), and organic molecules among which polyelectrolytes (soluble polymers, proteins, and polysaccharides). The literature concerning the effect of impurities on crystal growth is enormous and the reader is referred to Abbona and Aquilino (2010) for a review. In Earth science, Lorens (1981) was among the first to discuss the way growth rate affects element distribution between calcite and solution. He demonstrated that $\mathrm{Sr}$ increases with the precipitation rate of calcite. Staudt et al. (1994) gave an early review of the effect of growth rate on non-equilibrium anion and cation incorporation during crystal growth. The empirical tendency derived from these studies is that in a given environment, the content of compatible elements in calcite (most divalent cations with ionic radii close to $\mathrm{Ca}^{2+}$ such as $\mathrm{Mn}^{2+}, \mathrm{Fe}^{2+}, \mathrm{Co}^{2+}, \mathrm{Cd}^{2+}$ ) decreases with increasing growth rate, while the content of incompatible elements such as $\mathrm{Sr}^{2+}$ and $\mathrm{Ba}^{2+}$ increases (Staudt et al., 1994). In biogenic calcites, the situation is complicated by the fact that organic molecules are structurally incorporated, and form a hybrid nano-composite. 
A
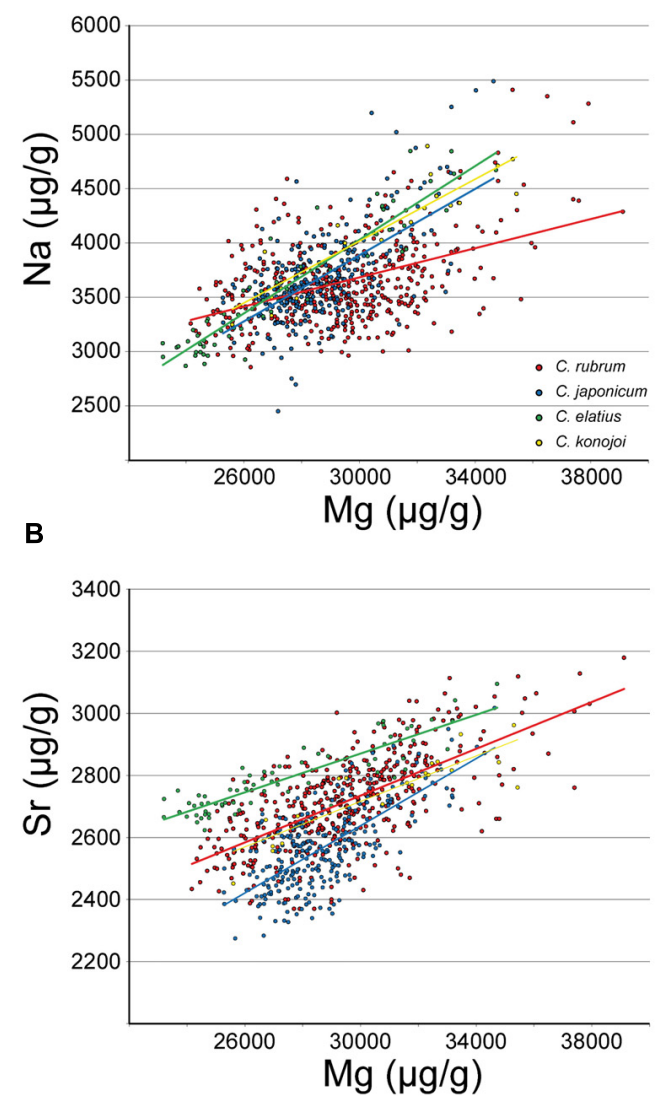

C

D
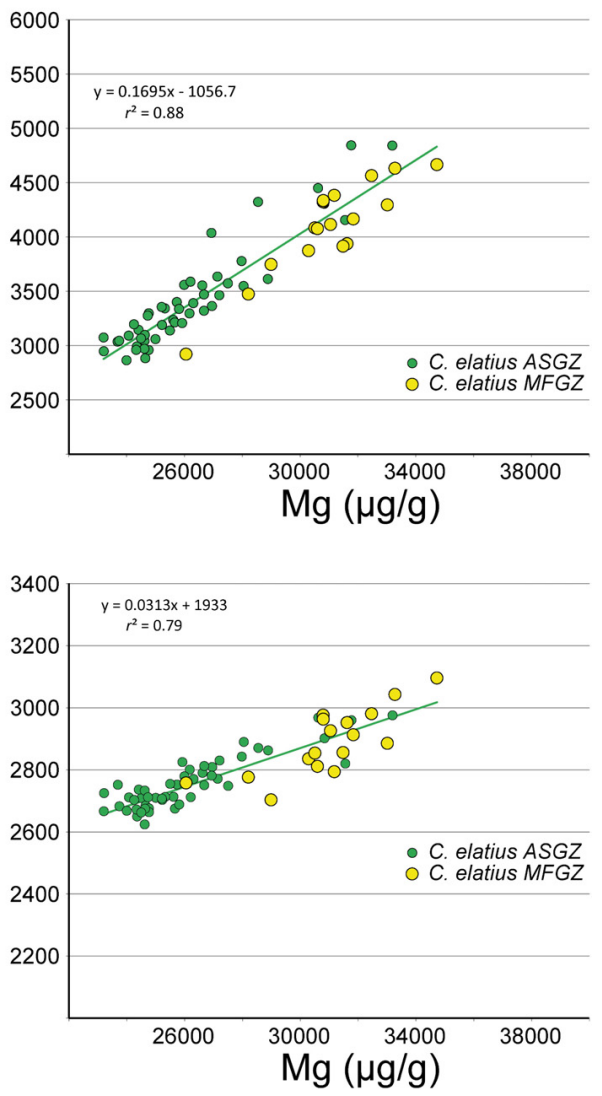

FIGURE 4 | LA-ICPMS data. (A,B) Na and Sr vs. Mg in C. rubrum, C. japonicum, C. elatius and C. konojoi and corresponding regression lines (equations and correlation coefficients are given as Supplementary Material SM1 Table 3). (C,D) C. elatius data extracted from (A,B) (equations and correlation coefficients from MFGZ and ASGZ combined data). ASGZ, annular slow growing zone; MFGZ, medullar fast growing zone.

Indeed, X-ray diffraction (Bischoff et al., 1983; Zolotoyabko, 2016) and synchrotron small and wide angle X-ray scattering (Gilow et al., 2011) indicate that lattice distortions in biogenic calcites originate from atomic interactions between crystal faces and organic molecules.

A review of experimental studies - Numerous experimental studies demonstrate that the incorporation of incompatible elements in inorganic calcite is favored by fast growth rates [Sr: (Lorens, 1981; Mucci, 1988; Tesoriero and Pankow, 1996; Gabitov and Watson, 2006; Tang et al., 2008); Ba: (Tesoriero and Pankow, 1996); Na: (Busenberg and Plummer, 1985; Mucci, 1988); U: (Bedzyk and Cheng, 2002; Weremeichik et al., 2017)]. Concerning lithium, data indicate that the Li/Ca ratio increases with aragonite precipitation rate (Gabitov et al., 2011), but, to our knowledge, this effect has not yet been confirmed in calcite. Interestingly, Okumura and Kitano (1986) observed positive correlations between $\mathrm{Li}$ and $\mathrm{Mg}$, and $\mathrm{Na}$ and $\mathrm{Mg}$ in synthetic calcites, as in the present biogenic calcites. Surprisingly, the case of magnesium, the major cation substituting to $\mathrm{Ca}$ in biogenic calcites, remains ambiguous. The amount of $\mathrm{Mg}$ incorporated in calcite overgrowth synthesized by Mucci and Morse (1983) were found to be independent of precipitation rate. On the other hand, Mavromatis et al. (2013) observed that calcite $\mathrm{Mg}$ contents increase with growth rate. Alternatively, Gabitov et al. (2014) observed an opposite effect between the incorporation of $\mathrm{Sr}$ and $\mathrm{Mg}$ and concluded that $\mathrm{Mg}$ content decreases with calcite increasing growth rate. Thus, the question of the influence of growth kinetics on $\mathrm{Mg}$ incorporation in calcite is still pending, even if the positive correlation between $\mathrm{Sr}$ and $\mathrm{Mg}$ observed in the present study seem to favor the conclusions of Mavromatis et al. (2013). The incorporation of anions in calcite has received less attention than the incorporation of cations. According to Busenberg and Plummer (1985), the amount of $\mathrm{SO}_{4}$ (and $\mathrm{Na}$ ) in calcite is directly related to growth rate. However, this conclusion is contradicted by the findings of Staudt et al. (1994) who observed that fast growing calcite faces [e.g., (11-20) and (01-12)] are depleted in $\mathrm{SO}_{4}$ (and enriched in $\mathrm{Mg}$ ) relative to slow growing (10-14) faces. To our knowledge, this is the only experimental evidence that the incorporation of $\mathrm{SO}_{4}$ in calcite decreases with precipitation rate. The variations of concentration in Corallium species are consistent with most of these experimental data in particular with respect to $\mathrm{Sr}, \mathrm{Na}, \mathrm{U}$, and Li. 

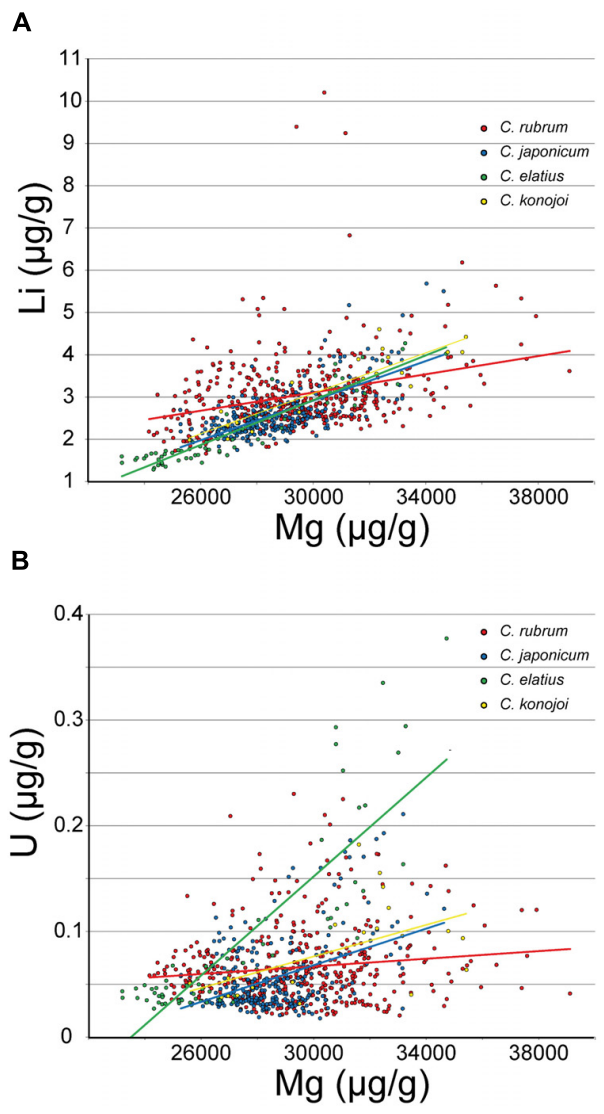

c

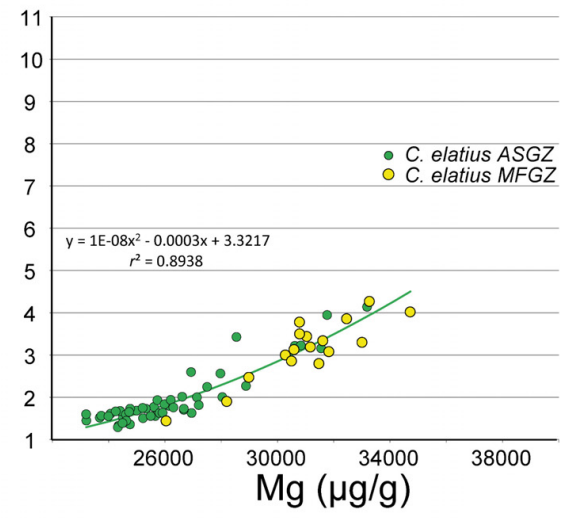

D

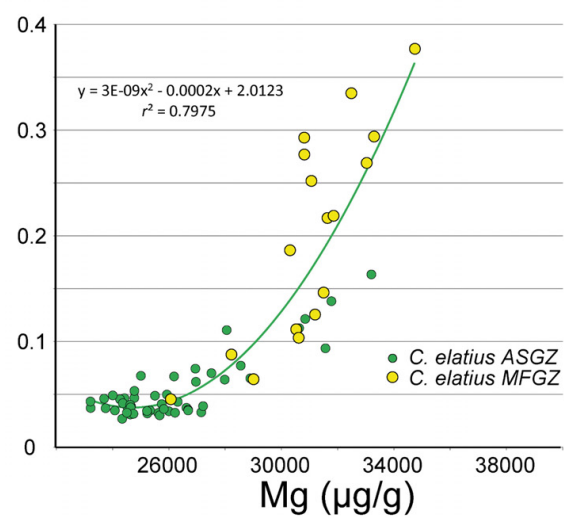

FIGURE 5 | LA-ICPMS data. (A,B) Li and U vs. Mg in C. rubrum, C. japonicum, C. elatius and C. konojoi (equations and correlation coefficients in Supplementary Material - SM1 Table 3). (C,D) C. elatius data extracted from (A,B) (equations and correlation coefficients from MFGZ and ASGZ combined data).

Substitution mechanisms - Substitution mechanisms in biogenic calcite are difficult to identify because of the complexity of the material. However, mechanisms proposed in previous studies can be discussed and new directions of work can be proposed. Pure (or close to pure) carbonate minerals exist for all cations considered here, and combinations between them $\left[\mathrm{CaCO}_{3}\right.$ : calcite; $\mathrm{MgCO}_{3}$ : magnesite; $\mathrm{Na}_{2} \mathrm{CO}_{3}$ : natrite; $\mathrm{SrCO}_{3}$ : strontianite; $\mathrm{Li}_{2} \mathrm{CO}_{3}$ : zabuyelite; $\mathrm{MnCO}_{3}$ : rhodochrosite; $\mathrm{BaCO}_{3}$ : witherite; $\mathrm{PbCO}_{3}$ : cerussite; $\mathrm{UO}_{2}\left(\mathrm{CO}_{3}\right)$ : rutherfordine; $(\mathrm{CaMg}) \mathrm{CO}_{3}$ : dolomite; $\mathrm{Na}_{2} \mathrm{Ca}\left(\mathrm{CO}_{3}\right)_{2}$ : nyerereite; $\mathrm{Na}_{2} \mathrm{Mg}\left(\mathrm{CO}_{3}\right)_{2}$ : eitelite; $\mathrm{BaMg}\left(\mathrm{CO}_{3}\right)_{2}$ : norsethite; $\mathrm{CaMn}\left(\mathrm{CO}_{3}\right)_{2}$ : kutnohorite]. Thus, the presence of $\mathrm{Mg}, \mathrm{Na}, \mathrm{Sr}, \mathrm{Li}, \mathrm{Ba}, \mathrm{Pb}$, and $\mathrm{U}$ in various amounts is expected in biogenic carbonates. It has been known for a long time that $\mathrm{Mg}$ substitutes to calcium and enters the calcite structure in large amounts (Mackenzie et al., 1983). Mucci and Morse (1983) documented a positive $\mathrm{Sr}-\mathrm{Mg}$ correlation in synthetic inorganic high-Mg calcites, and concluded that the incorporation of $\mathrm{Mg}$ in calcite could change the distribution coefficient of Sr. The positive correlation between $\mathrm{Mg}$ and $\mathrm{Sr}$ was explained by steric effects: a large cation ( $\mathrm{Sr}$ ) compensating the distortion produced in calcite by the introduction of small cation $(\mathrm{Mg})$. The sulfur case is more complicated: it has been demonstrated that sulfur is present as sulfate ions $\left(\mathrm{SO}_{4}{ }^{2-}\right)$ substituting to carbonate ions $\left(\mathrm{CO}_{3}{ }^{2-}\right)$ in
Corallium skeletons (Vielzeuf et al., 2013; Nguyen et al., 2014; Tamenori et al., 2014; Perrin et al., 2017). One would expect the lattice distortion related to the presence of a large anion $\left(\mathrm{SO}_{4}{ }^{2-}\right.$ larger than $\mathrm{CO}_{3}{ }^{2-}$ ) to be compensated by the incorporation of a small cation such as $\mathrm{Mg}$. The opposite is observed with a negative correlation between $\mathrm{Mg}$ and $\mathrm{S}$. This relationship could result from multicomponent substitutions generating complex interactions with effects difficult to predict. Due to charge balance, the incorporation of $\mathrm{Na}$ in calcite is problematic. Nevertheless sodium concentrations in biogenic calcites can reach several thousand $\mu \mathrm{g} / \mathrm{g}$ (see the review by Yoshimura et al., 2017). Different hypothesis for the substitution of $\mathrm{Na}$ in calcite have been proposed and have been summarized by these authors:

- $2 \mathrm{Ca}^{2+}=1 \mathrm{Na}^{+}+\mathrm{Me}^{3+}$ (Billings and Ragland, 1968)

- $\mathrm{Ca}^{2+}+\mathrm{CO}_{3}^{2-}=\mathrm{Na}^{+}+\mathrm{Cl}^{-}$(Yoshimura et al., 2017)

- $2 \mathrm{Ca}^{2+}=2 \mathrm{Na}^{+}+\square\left(\mathrm{CO}_{3}^{2-}\right.$ vacant site) (White, 1977; Yoshimura et al., 2017).

The first mechanism is unlikely in the Corallium case as the concentration of trivalent metals $\left(\mathrm{Me}^{3+}\right.$, e.g., $\left.\mathrm{Al}^{3+}\right)$ is considerably lower than the $\mathrm{Na}$ concentration. In this type of substitution, lanthanides are often considered potential substituting trivalent cations, but the REE concentrations are 


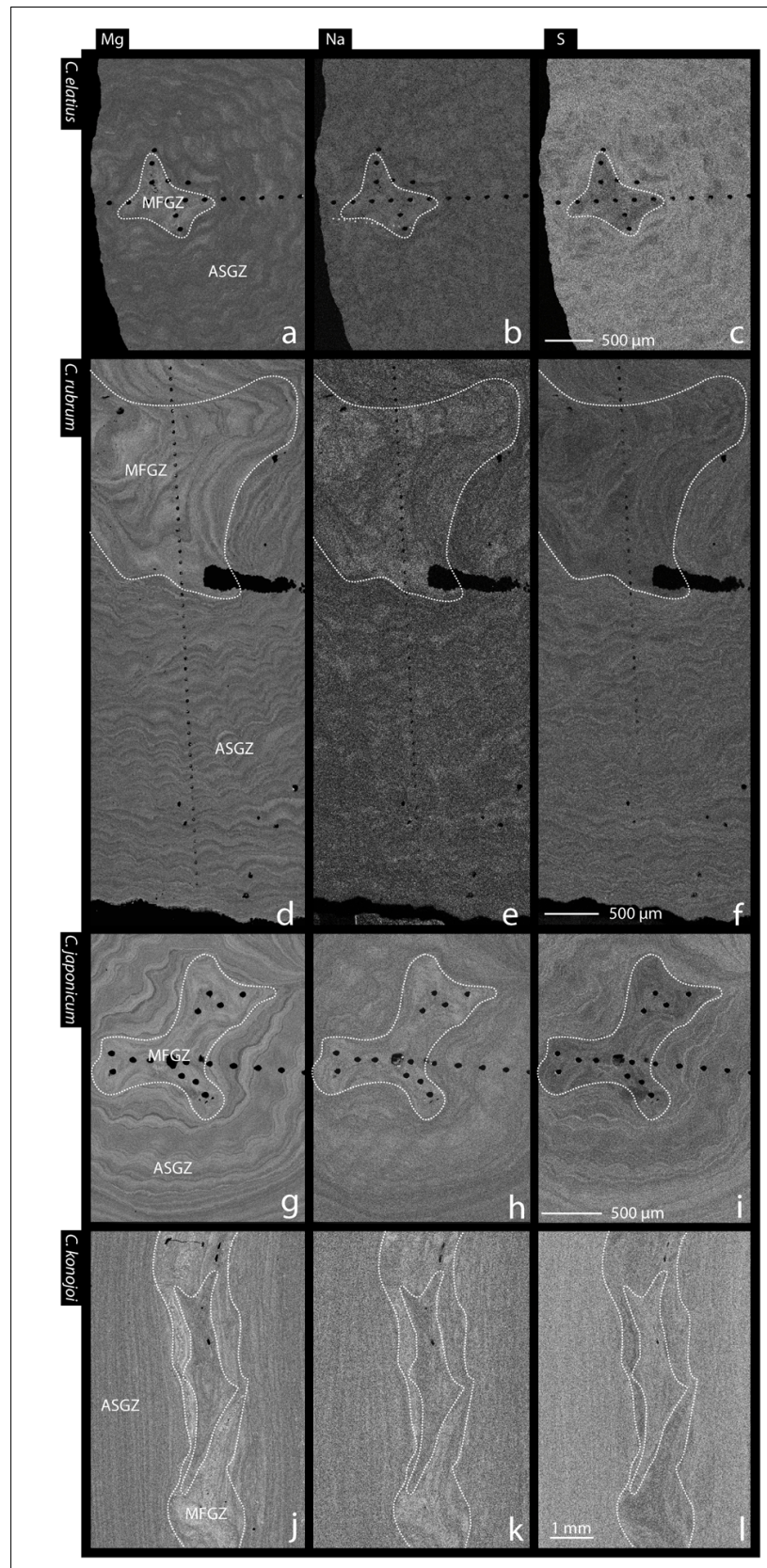

FIGURE 6 | Mg, Na and S EMP maps of Corallium skeletons. (a-c) Transverse section of $C$. elatius. (d-f) Transverse section of C. rubrum. (g-i) Transverse section of $C$. japonicum. (j-l) Longitudinal section of $C$. konojoi. White dashed lines encircle medullar zones. ASGZ, annular slow growing zone; MFGZ, medullar fast growing zone.

too low to retain this mechanism (see Table 3). Similar mass balance considerations apply for the second mechanism involving chlorine: according to the measurements carried out on C. rubrum, chlorine contents are too low (see Table 1). On the basis of synchrotron X-ray spectroscopy, Yoshimura et al. (2017) favored the third mechanism involving a carbonate vacancy. An alternative hypothesis can be proposed: White (1978) observed that $\mathrm{Na}$ content is higher in biogenic than in inorganic calcites and suggested that the presence of organic molecules in biogenic calcites could be responsible for this difference. A direct association between organic molecules and sodium at the atomic scale was recently demonstrated in biominerals by Branson et al. (2016). Bonding between hydrogen (from an organic molecule) and oxygen belonging to carbonate ion at the calcite surface is a potential linking mechanism (Ataman et al., 2016). Such an interaction could compensate the deficit of charge induced by the incorporation of Na. The substitution mechanism can be tentatively written as:

$$
\text { - } \mathrm{Ca}^{2+}+\mathrm{CO}_{3}^{2-}=\mathrm{Na}^{+}+\mathrm{HCO}_{3}^{-}
$$

where $\mathrm{HCO}_{3}{ }^{-}$would represent the bond between $\mathrm{OM}$ and calcite surface via hydrogen bonding. This hypothesis remains to be verified as other possibilities of interaction between $\mathrm{OM}$ and calcite surface exist (Mann et al., 1993; Sommerdijk and de With, 2008).

The present data underline the importance of $U$ to distinguish fast and slow growing zones. Yet, there is no consensus on the mechanism of incorporation of $U$ in calcite. Indeed, Reeder et al. (2000) consider that a uranyl unit $\left[\mathrm{UO}_{2}{ }^{2+}\right]$ is unable to reach a stable structural environment in calcite. On the contrary, Kelly et al. (2003) consider that uranyl has a stable lattice position in calcite. According to these authors, this substitution would result in a charge excess of +4 around the uranyl site because of the two missing carbonate ions and the substitution mechanism would be: $5 \mathrm{Ca}^{2+}=\mathrm{UO}_{2}{ }^{2+}+4 \mathrm{Na}^{+}$. In biogenic calcite, the presence of large amounts of $\mathrm{Na}$ could easily compensate the charge excess around the uranyl group, but the exact substitution mechanism of $\mathrm{U}$ remains to be determined.

A conceptual model for Corallium skeleton crystal growth As a possible scenario for Corallium skeleton growth, biogenic $\mathrm{Mg}$ calcites would grow extracellularly in a complex organic/inorganic solution with fluctuating compositions, dynamically regulated by the organism. The cations and anions required for the mineralization would be present in the solution (in forms that are not yet determined: possibly including organo-mineral polymers) together with a large variety of organic molecules (Debreuil et al., 2011), such as polyenic chains, responsible for the precious coral red color (Merlin and Dele-Dubois, 1986; Brambilla et al., 2012). As biogenic calcite would grow in the presence of impurities, the most compatible organic molecules would be incorporated on specific crystal faces and would induce defects that would facilitate the incorporation of other impurities (anions or cations) in the crystal (or conversely), in a constant feedback process. Simultaneously, fast crystal growth combined with steric constraints would allow non-equilibrium incorporation of more incompatible elements such as $\mathrm{Mg}, \mathrm{Sr}, \mathrm{Na}, \mathrm{Li}$, and U. Thus, skeleton growth would result from the competition between thermodynamic equilibrium and kinetic effects associated with (1) crystal growth rate, (2) diffusion of elements and molecules in the solution (in this scenario, intracrystalline diffusion is considered negligible), and (3) dynamic renewal (by addition and removal) of the solution by the organism. Interestingly, the concentration of elements and organic molecules not 

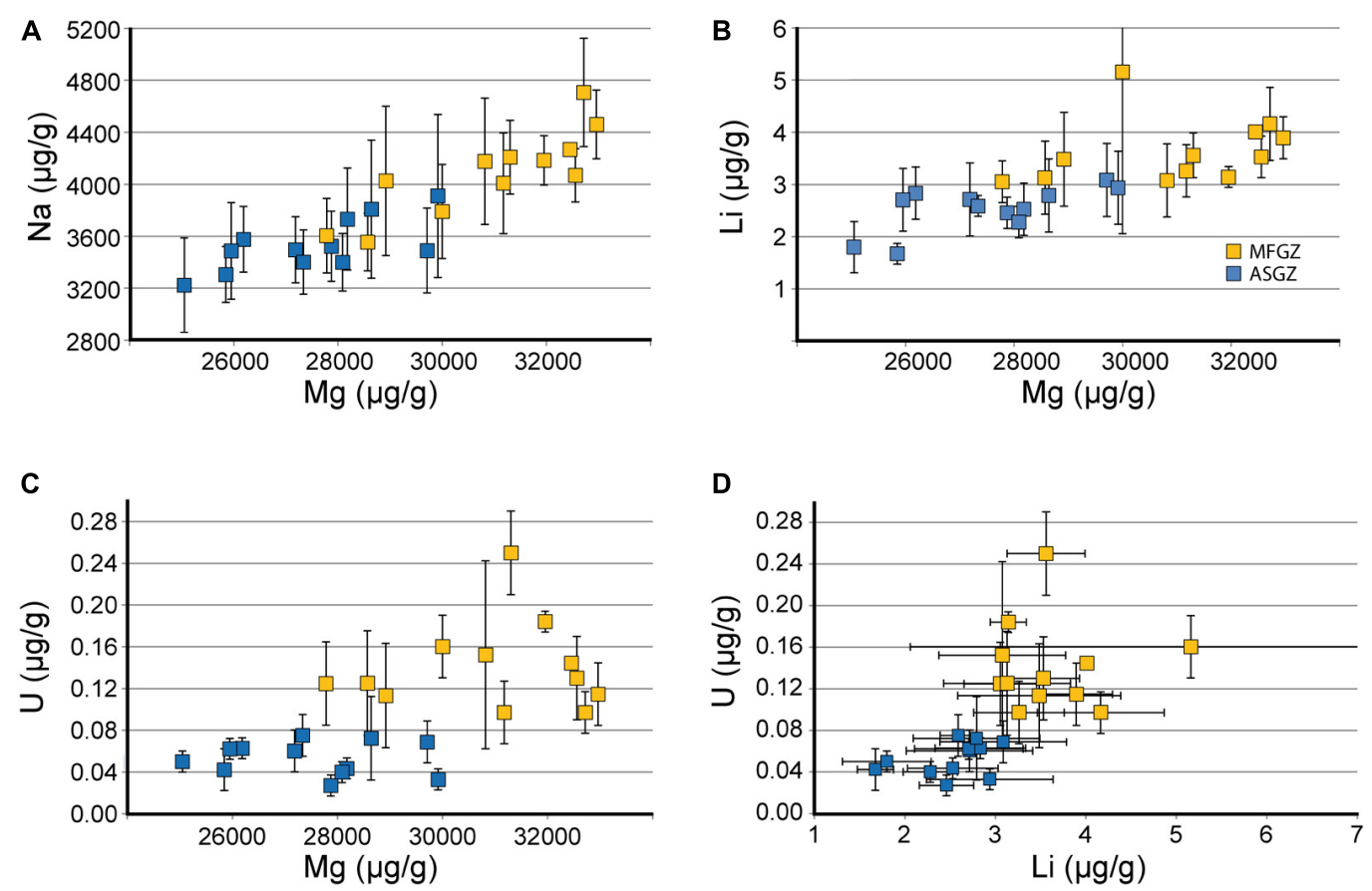

FIGURE 7 | Chemical comparison of medullar fast growing and annular slow growing zones (LA-ICPMS data). (A-C) Na, Li, and U vs. Mg. (D) U vs. Li. Mean compositions of annular slow growing zones (blue squares) and medullar fast growing zones (yellow squares) in C. rubrum, C. japonicum, C. elatius, and C. konojoi (undifferentiated). MFGZ, medullar fast growing zone; ASGZ, annular slow growing zone. Error bars correspond to standard deviations ( $\pm 1 \sigma \mathrm{SD}$ ) given in Supplementary Material SM1 Table 2. Horizontal SD for magnesium have not been reported for clarity (for each dot, the mean Mg SD is about $1,500 \mu \mathrm{g} / \mathrm{g}$ ).

incorporated in biogenic calcite could temporarily accumulate at the growth front and stop the skeleton growth, leading to crystallization pulses at the skeleton surface. A dynamic process of renewal of the solution (global exchange) would alternate with a more static situation during which local exchange between crystal and solution would take place, in a partially closed system. In such a situation, the composition of the solution may evolve depending upon the distribution coefficients of elements into that mineral. This process of Rayleigh fractionation leads to positive correlations between elements with partition coefficients less than 1 . Indeed, the correlations between $\mathrm{Mg} / \mathrm{Ca}$ and $\mathrm{Sr} / \mathrm{Ca}$ in the ID-ICPMS dataset (Figure 9) could be also explained by a Rayleigh fractionation process where calcite grows from an initial solution of seawater. The Rayleigh fractionation path displayed in Figure 9 is based on the following assumptions: (1) the initial calcifying fluid has $\mathrm{Sr} / \mathrm{Ca}$ and $\mathrm{Mg} / \mathrm{Ca}$ ratios that are the same as seawater $(8.6 \mathrm{mmol} / \mathrm{mol}$ and $5.1 \mathrm{~mol} / \mathrm{mol}$, respectively); (2) calcite partition coefficients are consistent with the inorganic data of Mucci and Morse (1983) and Mucci (1986) $\left(D_{\mathrm{Sr} / \mathrm{Ca}}=0.35\right.$ and $\left.D_{\mathrm{Mg} / \mathrm{Ca}}=0.0215\right)$. It is of course likely that the calcifying fluid has a different composition than seawater, but we think that these are reasonable assumptions in the absence of direct measurements of the calcifying fluid. The fractionation path shown in Figure 9 indicates that the model fits rather well the data. Thus, Rayleigh fractionation could be part of the explanation for observed $\mathrm{Mg} / \mathrm{Ca}$ vs. $\mathrm{Sr} / \mathrm{Ca}$ correlations.

Concerning the calcifying fluid, whether ion fluxes between sea water and the surface of calcification occur (1) through tissues by active transcellular transport or by paracellular pathways (i.e., between the cells) (e.g., Tambutté et al., 2012; Taubner et al., 2017), or (2) by direct and rapid seawater transport to the site of calcification (e.g., Bentov et al., 2009; Gagnon et al., 2012), is not known. Nevertheless, putting emphasis on kinetic effects, as we do in the present work, implies that calcifying fluids and their mechanisms of formation are similar in fast and slow growing zones. The fact that geochemical trends are identical in the two zones (see for instance Figures 2D-F, 4C,D, 5C,D for the C. elatius case) favors a similarity of mechanism of formation of the calcifying fluid. It will be noted that geochemical trends slightly vary from a species to another, possibly indicating some physiological differences of formation of the calcifying fluid in the different species. Contrary to medullar and annular zones, sclerites, and skeletons of C. rubrum display separate $\mathrm{Mg} / \mathrm{Sr}$ trends in Figure 9. In this case, differences of composition between sclerites and skeleton can be tentatively ascribed (at least partly) to differences of calcifying fluid, themselves related to differences of mechanism of formation of the skeleton and the sclerites. Indeed, while the formation of the skeleton takes place extracellularly, the early stages of formation of sclerites take place intracellularly in a primary scleroblast, then in a highly confined extracellular medium formed by only two secondary scleroblasts (Le Goff et al., 2017).

To conclude, kinetic factors are considered of importance in this study, but they do not exclusively control the chemical variations of precious coral skeletons; indeed, our model represents a possible but not a unique explanation for the data. 

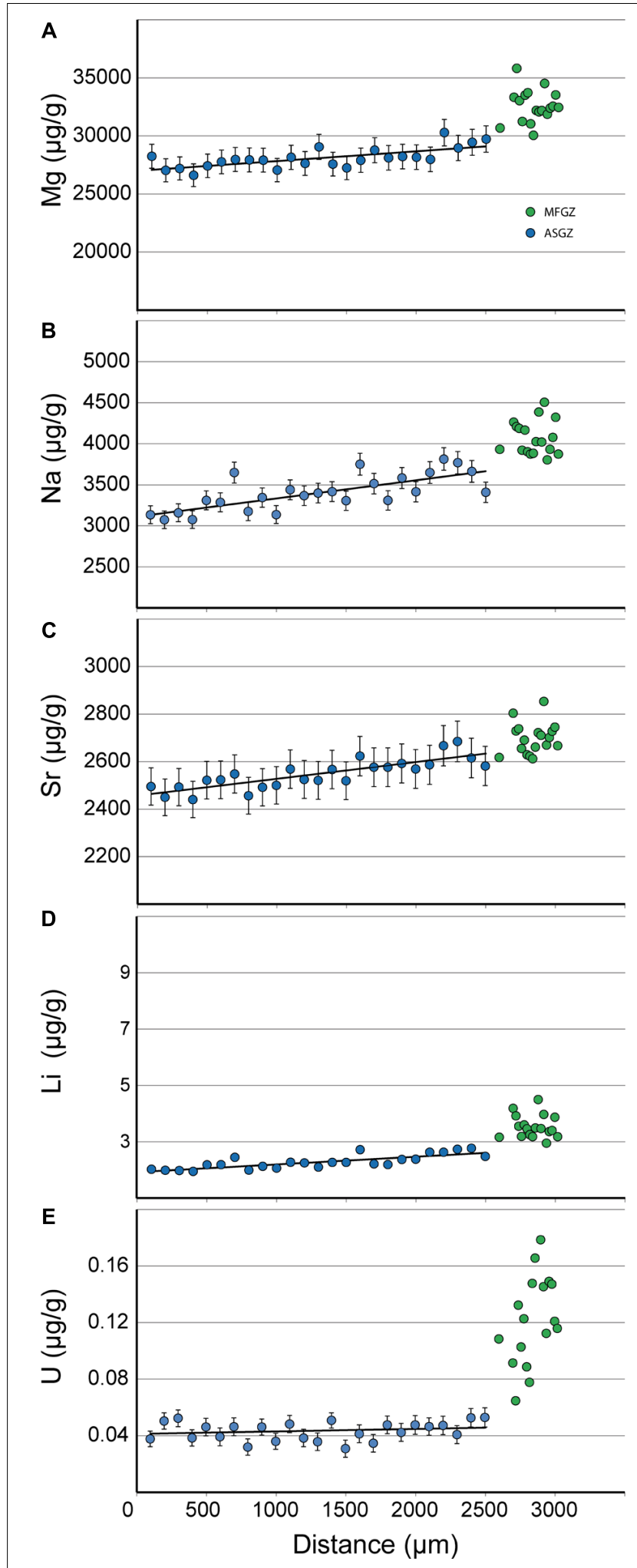

FIGURE 8 | LA-ICPMS analytical traverse in C. konojoi. (A-E) Mg, Na, Sr, Li, and $U$ traverses in a section of $C$. konojoi. Some analytical points in the medullar zone are not aligned along the traverse (see Figure 1d for a case of misalignment in the medullar zone). Error bars for lithium are smaller than the dot. Error bars in the medullar zone are not reported for clarity.

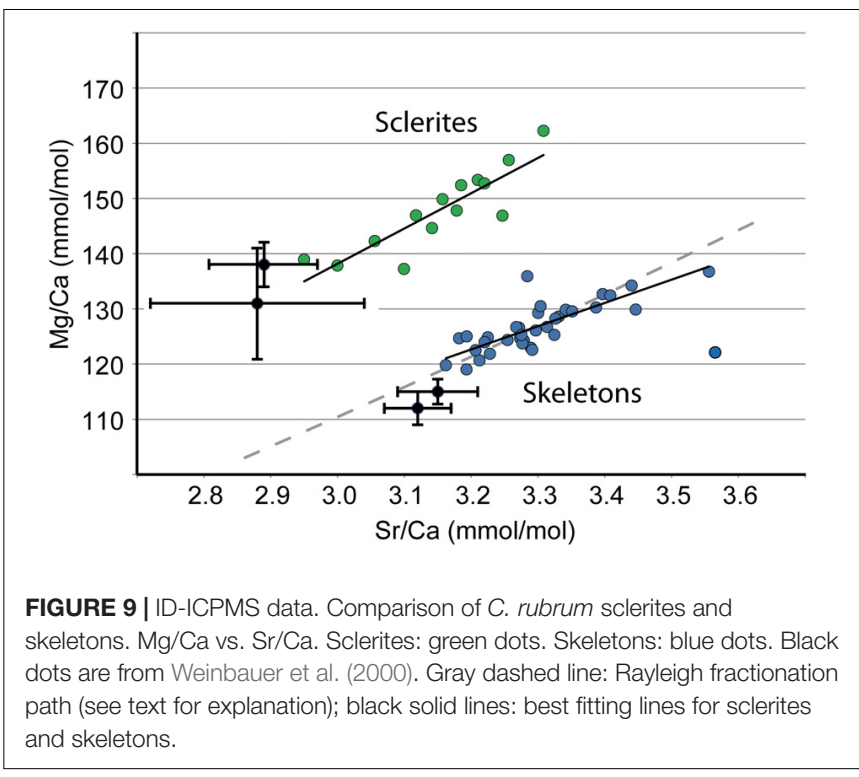

The impurity incorporation/repulsion model proposed here is based on the concept of growth entrapment grasped decades ago by Kinsman and Holland (1969) and popularized by Watson (2004) who formalized a model to investigate hypothetical calcite growth scenarios. Though originally designed for abiogenic crystals, the growth entrapment model has been invoked to explain variations of concentrations of magnesium in brachiopod calcitic shells (Rollion-Bard et al., 2016). The present model differs from the growth entrapment model by the facts that (i) incorporation of organic molecules plays a part in the process, (ii) the accumulation of incompatible elements or organic molecules at the growth front may interrupt crystal growth, and induce crystallization pulses, and (iii) biological rhythms inducing dynamic renewal (by addition and removal) of the solution are essential parts of the process.

\section{Comparison With Other Fast and Slow Growing Zones in Calcitic and Aragonitic Biominerals}

Comparative studies of fast and slow growing zones in calcitic biominerals are rare. Thébault and Chauvaud (2012) noted that the $\mathrm{Li} / \mathrm{Ca}$ ratios in the central axis (with faster growth rate) of Pecten maximus were higher than around it. These differences are explained by faster daily growth rates in central axis than in lateral ribs. Yoshimura et al. (2017, their Figure 6) observed a core enriched in $\mathrm{Mg}$ and depleted in $\mathrm{S}$ in a Japanese precious pink coral, as in C. rubrum (Figure 3 in Vielzeuf et al., 2008) confirming that these features are systematic in Corallium species (Figure 4 in Perrin et al., 2015). In the calcitic central core of the deep-water bamboo coral Keratoisis sp., Sinclair et al. (2011) observed an enrichment in Ba and Mg; these authors concluded that the central axis of the skeleton may represent a different mode of growth than its periphery. Contrary to biogenic calcites, biogenic aragonites gave rise to numerous comparative 
studies of fast and slow growing zone. As summarized by RollionBard and Blamart (2015), scleractinian coral skeletons made of aragonite are characterized by two types of internal structures: rapid accretion deposits (RADs; Stolarski, 2003), also referred to as early mineralization zones (EMZs; Cuif et al., 2003) or centers of calcification (COC; Wells, 1956), in between thickening deposits (TDs; Stolarski, 2003 - also called fibers - Ogilvie, 1896). RAD are enriched in Mg (Meibom et al., 2004; Meibom et al., 2006; Gagnon et al., 2007; Brahmi et al., 2012; Montagna et al., 2014; Rollion-Bard and Blamart, 2015). The status of Sr is not so clear: following Ferrier-Pagès et al. (2002), Meibom et al. (2004) stated that the $\mathrm{Sr}$ uptake is inversely correlated with the rate of calcification in Pavona clavus. However, this statement was contradicted by observations on Colpophyllia sp. showing that RAD were enriched in $\mathrm{Mg}, \mathrm{Sr}, \mathrm{B}, \mathrm{S}$, and $\mathrm{Ba}$ (Meibom et al., 2006). Case et al. (2010) and later Montagna et al. (2014) analyzed a large suite of aragonite coral skeletons and showed that $\mathrm{Li}$ and $\mathrm{Mg}$ are positively correlated and that RAD are enriched in these two elements. Using three scleractinian corals as models, Rollion-Bard and Blamart (2015) showed that $\mathrm{RAD}$ are enriched in $\mathrm{Mg}, \mathrm{Na}$, and $\mathrm{Li}$; they observed a positive correlation between $\mathrm{Na}$ and $\mathrm{Mg}$ and confirmed the $\mathrm{Li} / \mathrm{Mg}$ correlation demonstrated by Case et al. (2010) and Montagna et al. (2014). In many of these works, kinetics effects were considered a factor for the preferential incorporation of elements in aragonite, but other mechanisms such as Rayleigh fractionation have also been invoked. Note that, since aragonite and calcite have different crystallographic structure and that structural aspects are of major importance in the incorporation of impurities, the results on aragonite corals, and especially elemental correlation, are difficult to compare with calcitic corals. Nevertheless, the presence of (1) fast and slow growing zones in both hexa- and octocorals, with block and cement mode of growth in the fast growing zone, and layer by layer mode in the slow growing zone (see Gladfelter, 1982; Perrin et al., 2015; for hexa- and octocoral growth modes, respectively), and (2) systematic differences in chemical composition between the two types of zones, indicate a possible convergence of factors (including growth rate) influencing the chemistry of calcium carbonates during growth.

\section{The Origin of Annual Growth Rings in C. rubrum}

The origin of chemical oscillations in annual growth rings, within the annular zone in Corallium skeletons is still unclear. Two facts lead to consider that annual growth rings may result in part from variations of growth rate during the year: (1) the study of Vielzeuf et al. (2013) demonstrated that the variations of $\mathrm{Mg}$ and $\mathrm{Sr}$ in the growth rings could not be correlated with sea water temperature; (2) the correlations between elements such as Na-Mg, Na-S, S-Mg, Sr-Mg, Li-Mg, U-Mg follow the same trends in medullar and annular zones. Thus, it is reasonable to consider that fast growth would produce ring portions rich in $\mathrm{Mg}, \mathrm{Sr}, \mathrm{Na}, \mathrm{Li}$, and $\mathrm{U}$, while slow growth would produce the $\mathrm{Ca}$ and S-rich portions. Marschal et al. (2004) conducted a series of experiments to determine the period of the year during which OM-rich bands develop in C. rubrum. Twelve colonies collected at $15 \mathrm{~m}$ depth were labeled with calcein in November 2001, March, and July 2002. Nine colonies were recovered December 2002, about a year after the first labeling. These colonies showed that late fall and winter is the period during which the narrow OM-rich band develops. Marschal et al. (2004) also concluded that late fall and winter is the period with the lowest growth rates in C. rubrum. Combining these observations with their own data, Vielzeuf et al. (2013) showed that Mg-rich rings develop during the period spring to fall while S-rich rings form immediately after (late fall and winter). The situation of sulfur in the skeleton is particularly difficult to understand and deserves further consideration. Vielzeuf et al. (2013) showed two types of spatial anti-correlations: $\mathrm{OM}$ and $\mathrm{Mg}, \mathrm{Mg}$ and $\mathrm{S}$, with the consequence that $\mathrm{OM}$ and $\mathrm{S}$ are correlated. A logical conclusion would be to consider that $S$ is present in the OM. However, Vielzeuf et al. (2013) pointed out that OM could not contain the measured amounts of $S$ and thus, that important portion had to be present as structurally substituted sulfate in calcite. This hypothesis was verified by Nguyen et al. (2014), Tamenori et al. (2014), and Perrin et al. (2017), who performed XANES studies on C. elatius, C. japonicum, and C. rubrum skeletons, respectively. The three studies demonstrated that $\mathrm{S}$ is mainly present as $\mathrm{SO}_{4}{ }^{2-}$ and incorporated as sulfur structurally substituted to carbonate (SSS - synonymous of carbonate associated sulfate - CAS). Thus, the most plausible hypothesis to explain the observed positive correlation between $\mathrm{S}$ and $\mathrm{OM}$ in C. rubrum is to consider that OM-rich rings are also made of calcite rich in structurally substituted sulfate. This conclusion is consistent with the hypothesis discussed earlier that S-rich calcite and OM-rich rings are indicative of slow growth rates. Concerning the medullar zone, the facts that no obvious periodic chemical oscillations is observed (at least so far) along the branch axis (e.g., Figures $\mathbf{6 j}-\mathbf{l}$ ) and that the medullar zone is systematically poorer in $\mathrm{S}$ and richer in $\mathrm{Mg}$ than the annular zone indicate that the medullar axial growth is discontinuous in time and happens preferentially during the period spring to fall. Due to similarity of growth processes (Perrin et al., 2015), we can reasonably hypothesize that the considerations on the origin of growth rings in C. rubrum apply to other Corallium species.

\section{Implication for the Use of Proxies in Corallium Species}

The present study reiterates the idea that the incorporation of ions during crystal growth depends in part on growth kinetics (Lorens, 1981; Staudt et al., 1994). However, it should be kept in mind that growth kinetics is not an independent variable as it is affected by the organism biological activity which is itself dependent on environmental parameters such as temperature, $\mathrm{pH}$, salinity, nutrient supply, etc. (Shinn, 1966). In the case of C. rubrum, the fact that fast growth happens during the hottest period of the year (spring to fall) is an indication of a temperature and growth interdependence. But this relation is complex and complicated by the thermo-tolerance of the organism: indeed, experiments carried out in aquaria showed that calcification rates of C. rubrum decrease above $21^{\circ} \mathrm{C}$ and that exposure to $25^{\circ} \mathrm{C}$ for durations between 9 and 14 days causes mortality of 
most samples (Torrents et al., 2008). Most elements discussed in this study $(\mathrm{Mg}, \mathrm{Sr}, \mathrm{Na}, \mathrm{Li}, \mathrm{Ba}, \mathrm{U})$ have been considered as environmental proxies in calcitic biominerals [Mg: (Rosenthal et al., 1997), Sr: (Yu et al., 2014), Na: (Yoshimura et al., 2017), Li: (Thébault and Chauvaud, 2012), Ba: (Yoshimura et al., 2015), U: (Yoshimura et al., 2015) and references therein]. Thus, the influence of environmental parameters cannot be discarded in the Corallium case.

If kinetics seems to play a role in the incorporation of $\mathrm{Mg}$, $\mathrm{Na}, \mathrm{Sr}, \mathrm{Li}$, and $\mathrm{U}$, it does not affect barium and lead as these two elements have similar contents in fast and slow growing zones. These features are indications that their concentrations could reflect the concentrations and fluctuations with space and time of $\mathrm{Ba}$ and $\mathrm{Pb}$ in the seawater. This conclusion is in agreement with observations obtained on the Bamboo coral, and the statement that in this species external environmental conditions control the skeletal $\mathrm{Ba}$ incorporation in calcite rather than internal biological effects (LaVigne et al., 2011). As seen above, the barium content is higher in the Mediterranean C. rubrum than in the Pacific C. japonicum (Figure 3) which makes the absolute value of $\mathrm{Ba}$ a good criterion to identify the two species (for instance in past or present day jewels or traded corals). Hasegawa et al. (2012) indicated that the $\mathrm{Ba} / \mathrm{Ca}$ ratio could be used to determine the geographic origin of Corallium species. However, Yoshimura et al. (2015) showed that the Ba content of Japanese corals increases at ocean depths beneath about $300 \mathrm{~m}$, to reach values close to those of the Mediterranean coral. Thus, deep Japanese coral could have similar Ba contents than near surface Mediterranean corals. The change of Ba content with depth might explain the range of $\mathrm{Ba}$ concentrations in the three studied Pacific coral species observed in Figure 3B. Thus, the Ba identification criterion alone might not be sufficient to discriminate Mediterranean and Pacific corals. We showed above that lead contents in Mediterranean corals are higher than in their Pacific counterparts. Here again, no difference of concentration of $\mathrm{Pb}$ was observed between medullar fast growing and annular slow growing zones in C. rubrum, and C. japonicum, nor between skeleton, tips and sclerites in C. rubrum, meaning that kinetics may not play an important role in the incorporation of $\mathrm{Pb}$ in biogenic calcites. To summarize, as a first simple criterion, $\mathrm{Ba}$ and $\mathrm{Pb}$ contents higher than 6 and $0.2 \mu \mathrm{g} / \mathrm{g}$, respectively, in a red precious coral of unknown origin can be considered indicative of a Mediterranean origin of the sample (Figure 3).

\section{CONCLUSION}

Emphasis on crystal growth kinetics or environmental parameters to explain biogenic calcite compositions should not hide the bigger picture. The fact that the mean magnesium contents of calcitic biominerals growing in similar environments vary from a species to another between 0 and $\sim 30 \mathrm{~mol}^{\circ} \mathrm{MgCO}_{3}$ cannot be ascribed to growth kinetics, nor environmental parameters. Genetic coding and physiology of each species are obviously of primary importance. Here, we are just evaluating the narrower and more tractable question of whether the variability of composition around the mean concentrations of a given species is consistent or not with kinetic effects. It is well known that living processes occur away from equilibrium. Biominerals produced by living organisms are no exception. Crystallographic hierarchical structures, chemical heterogeneities and complex morphologies are unambiguous indications that biominerals do not simply follow free energy minimization principles. Their construction under the influence of organisms involves a variety of biological, chemical and physical periodic processes. Some like biological factors, growth kinetics, periodic renewal/removal of the solution, and environmental changes may drive biogenic calcites away from global equilibrium, while others such as crystallization, Rayleigh fractionation, or diffusion in the solution, push them toward it. The role of each process probably changes from a species to another, and even within a single organism depending on the period of the year and the location of calcification within the organism. Identifying the implication of each process in Corallium chemical variability and understanding skeleton growth dynamics are difficult goals to achieve but remain necessary steps for environmental applications.

\section{AUTHOR CONTRIBUTIONS}

DV and NF conceived the project. DV, J-LD, and JP collected the EMP data. DV, AR, J-LD, NY, and JP collected LA-ICPMS data. DV prepared the samples. AG collected the ID-ICPMS data. CF, DV, and JP collected OEA data. JG collected and supplied some samples from the Mediterranean. $\mathrm{CB}-\mathrm{H}$ provided rare samples from her personal collection. J-MM performed the statistical analysis of the data. All authors participated to the interpretation of the data. DV wrote the first draft of the manuscript and all authors participated in the subsequent stages of preparation of the manuscript.

\section{FUNDING}

This work has been supported by the Centre National de la Recherche Scientifique (CNRS), by the Institut National des Sciences de l'Univers (INSU) through grant INTERRVIE 2017 to DV, by the Agence Nationale pour la Recherche (ANR) through ANR CoRo 2011-2015, by the Centre Interdisciplinaire de Nanoscience de Marseille (CINaM) through internal grants, and by the European Union COST action TD0903. This study benefited from the generosity of numerous contributors who supplied rare samples.

\section{ACKNOWLEDGMENTS}

We thank P. Raffin, J. G. Harmelin, and C. Marschal for providing C. rubrum colonies from various places in the Mediterranean. Samples of C. japonicum, C. elatius, and C. konojoi were kindly provided by S. Tambutté from Centre Scientifique of Monaco, and G. Tanaka from the Precious Coral Protection and Development Association. We also thank K. Saiki from 
Osaka University for initiating the fruitful exchange with G. Tanaka. Rare specimens of C. johnsoni and C. niobe were provided by F. J. de Mora Porteiro from the Department of Oceanography and Fisheries, University of the Azores. Finally, we are grateful to P. Lozouet, C. Dupoux, P. Joannot, and A. Andouche from the Museum National d'Histoire Naturelle, Paris (MNHN) for providing the paratype of $P$. thrinax (MNHN-Oct-243). Comments by Rinat Gabitov, Thomas DeCarlo, and Hans Dahms as well as efficient editorial handling

\section{REFERENCES}

Abbona, F., and Aquilino, D. (2010). "Mophology of crystal grown in solution," in Springer Handbook of Crystal Growth, eds G. Danaraj, K. Byrappa, V. Prasad, and M. Dudley (Berlin: Springer-Verlag), 53-92.

Allemand, D. (1993). The biology and skeletogenesis of the mediterranean red coral - a review. Precious Corals Octocoral Res. 2, 19-39.

Ataman, E., Andersson, M. P., Ceccato, M., Bovet, N., and Stipp, S. L. S. (2016). Functional group adsorption on calcite: I. oxygen containing and nonpolar organic molecules. J. Phys. Chem. C 120, 16586-16596. doi: 10.1021/acs.jpcc. $6 \mathrm{~b} 01349$

Bedzyk, M. J., and Cheng, L. W. (2002). X-ray standing wave studies of minerals and mineral surfaces: principles and applications. Rev. Miner. Geochem. 49, 221-266. doi: 10.2138/gsrmg.49.1.221

Bentov, S., Brownlee, C., and Erez, J. (2009). The role of seawater endocytosis in the biomineralization process in calcareous foraminifera. Proc. Natl. Acad. Sci. U.S.A. 106, 21500-21504. doi: 10.1073/pnas.0906636106

Billings, G. K., and Ragland, P. C. (1968). Geochemistry and mineralogy of the recent reef and lagoonal sediments south of Belize (British Honduras). Chem. Geol. 3, 135-153. doi: 10.1016/0009-2541(68)90006-5

Bischoff, W. D., Bishop, F. C., and Mackenzie, F. T. (1983). Biogenically produced magnesian calcite inhomogeneities in chemical and physicalproperties comparison with synthetic phases. Am. Mineral. 68, 1183-1188.

Brahmi, C., Kopp, C., Domart-Coulon, I., Stolarski, J., and Meibom, A. (2012). Skeletal growth dynamics linked to trace-element composition in the scleractinian coral Pocillopora damicornis. Geochim. Cosmochim. Acta 99, 146-158. doi: 10.1016/j.gca.2012.09.031

Brambilla, L., Tommasini, M., Zerbi, G., and Stradi, R. (2012). Raman spectroscopy of polyconjugated molecules with electronic and mechanical confinement: the spectrum of Corallium rubrum. J. Raman Spectrosc. 43, 1449-1458. doi: 10. 1002/jrs.4057

Branson, O., Bonnin, E. A., Perea, D. E., Spero, H. J., Zhu, Z. H., Winters, M., et al. (2016). Nanometer-scale chemistry of a calcite biomineralization template: implications for skeletal composition and nucleation. Proc. Natl. Acad. Sci. U.S.A. 113, 12934-12939. doi: 10.1073/pnas.1522864113

Busenberg, E., and Plummer, N. L. (1985). Kinetic and thermodynamic factors controlling the distribution of $\mathrm{SO}_{3}^{2-}$ and $\mathrm{Na}^{+}$in calcites and selected aragonites. Geochim. Cosmochim. Acta 49, 713-725. doi: 10.1016/0016-7037(85) 90166-8

Carignan, J., Hild, P., Mevelle, G., Morel, J., and Yeghicheyan, D. (2001). Routine analyses of trace elements in geological samples using flow injection and low pressure on-line liquid chromatography coupled to ICP-MS: a study of geochemical reference materials BR, DR-N, UB-N, AN-G and GH. Geostand. Newsl. 25, 187-198. doi: 10.1111/j.1751-908X.2001.tb00595.x

Case, D. H., Robinson, L. F., Auro, M. E., and Gagnon, A. C. (2010). Environmental and biological controls on $\mathrm{Mg}$ and $\mathrm{Li}$ in deep-sea scleractinian corals. Earth Planet Sci. Lett. 300, 215-225. doi: 10.1016/j.epsl.2010.09.029

Cuif, J. P., Lecointre, G., Perrin, C., Tillier, A., and Tillier, S. (2003). Patterns of septal biomineralization in Scleractinia compared with their $28 \mathrm{~S}$ rRNA phylogeny: a dual approach for a new taxonomic framework. Zool. Scr. 32, 459-473. doi: 10.1046/j.1463-6409.2003.00133.x

Debreuil, J., Tambutté, É., Zoccola, D., Deleury, E., Guigonis, J. M., Samson, M., et al. (2012). Molecular cloning and characterization of first organic matrix protein from sclerites of red coral, Corallium rubrum. J. Biol. Chem. 287, 19367-19376. doi: 10.1074/jbc.M112.352005 by KB are gratefully acknowledged. This is contribution ANR CoRo ${ }^{\circ} 11$.

\section{SUPPLEMENTARY MATERIAL}

The Supplementary Material for this article can be found online at: https://www.frontiersin.org/articles/10.3389/feart. 2018.00167/full\#supplementary-material

Debreuil, J., Tambutté, S., Zoccola, D., Segonds, N., Techer, N., Marschal, C., et al. (2011). Specific organic matrix characteristics in skeletons of Corallium species. Mar. Biol. 158, 2765-2774. doi: 10.1007/s00227-011-1775-7

Ferrier-Pagès, C., Boisson, F., Allemand, D., and Tambutté, E. (2002). Kinetics of strontium uptake in the scleractinian coral Stylophora pistillata. Mar. Ecol. Prog. Ser. 245, 93-100. doi: 10.3354/meps245093

Gabitov, R. I., Sadekov, A., and Leinweber, A. (2014). Crystal growth rate effect on $\mathrm{Mg} / \mathrm{Ca}$ and $\mathrm{Sr} / \mathrm{Ca}$ partitioning between calcite and fluid: an in situ approach. Chem. Geol. 367, 70-82. doi: 10.1016/j.chemgeo.2013.12.019

Gabitov, R. I., and Watson, E. B. (2006). Partitioning of strontium between calcite and fluid. Geochem. Geophys. Geosyst. 7:Q11004.

Gabitov, R. I., Schmitt, A. K., Rosner, M., McKeegan, K. D., Gaetani, G. A., Cohen, A. L., Watson, E. B., Harrison, T. M., (2011). In situ $\delta^{7} \mathrm{Li}, \mathrm{Li} / \mathrm{Ca}$, and $\mathrm{Mg} / \mathrm{Ca}$ analyses of synthetic aragonites. Geochem. Geophys. Geosyst. 12:Q03001.

Gagnon, A. C., Adkins, J. F., and Erez, J. (2012). Seawater transport during coral biomineralization. Earth Planet Sci. Lett. 329, 150-161. doi: 10.1016/j.epsl.2012. 03.005

Gagnon, A. C., Adkins, J. F., Fernandez, D. P., and Robinson, L. F. (2007). Sr/Ca and $\mathrm{Mg} / \mathrm{Ca}$ vital effects correlated with skeletal architecture in a scleractinian deep-sea coral and the role of Rayleigh fractionation. Earth Planet Sci. Lett. 261, 280-295. doi: 10.1016/j.epsl.2007.07.013

Gao, S., Liu, X. M., Yuan, H. L., Hattendorf, B., Gunther, D., Chen, L., et al. (2002). Determination of forty two major and trace elements in USGS and NIST SRM glasses by laser ablation-inductively coupled plasma-mass spectrometry. Geostand. Newsl. 26, 181-196. doi: 10.1111/j.1751-908X.2002.tb00886.x

Garrabou, J., and Harmelin, J. G. (2002). A 20-year study on life-history traits of a harvested long-lived temperate coral in the NW Mediterranean: insights into conservation and management needs. J. Anim. Ecol. 71, 966-978. doi: 10.1046/j.1365-2656.2002.00661.x

Gilow, C., Zolotoyabko, E., Paris, O., Fratzl, P., and Aichmayer, B. (2011). Nanostructure of biogenic calcite crystals: a view by small-angle X-Ray scattering. Cryst. Growth Des. 11, 2054-2058. doi: 10.1021/cg200136t

Gladfelter, E. H. (1982). Skeletal development in Acropora cervicornis: I. Patterns of calcium carbonate accretion in the axial corallite. Coral Reefs 1, 45-51. doi: 10.1007/BF00286539

Hasegawa, H., Rahman, M. A., Luan, N. T., Maki, T., and Iwasaki, N. (2012). Trace elements in Corallium spp. as indicators for origin and habitat. J. Exp. Mar. Biol. Ecol. 414, 1-5. doi: 10.1016/j.jembe.2012.01.005

Kelly, S. D., Newville, M. G., Cheng, L., Kemner, K. M., Sutton, S. R., Fenter, P., et al. (2003). Uranyl incorporation in natural calcite. Environ. Sci. Technol. 37, 1284-1287. doi: 10.1021/es025962f

Kinsman, D. J. J., and Holland, H. D. (1969). The co-precipitation of cations with $\mathrm{CaCO}_{3}-\mathrm{IV}$. The co-precipitation of $\mathrm{Sr}^{2+}$ with aragonite between $16^{\circ}$ and $96^{\circ}$. Geochim. Cosmochim. Acta 33, 1-17. doi: 10.1016/0016-7037(69)90089-1

Lacaze-Duthiers, H. (1864). Histoire Naturelle du Corail, ed. J. B. Bailière et Fils, Cambridge, MA: Harvard University.

LaVigne, M., Hill, T. M., Spero, H. J., and Guilderson, T. P. (2011). Bamboo coral $\mathrm{Ba} / \mathrm{Ca}$ : calibration of a new deep ocean refractory nutrient proxy. Earth Planet Sci. Lett. 312, 506-515. doi: 10.1016/j.epsl.2011.10.013

Le Goff, C., Tambutté, E., Venn, A. A., Techer, N., Allemand, D., Tambutté, S., 2017. In vivo $\mathrm{pH}$ measurement at the site of calcification in an octocoral. Sci. Rep. 7:11210.

Lorens, R. B. (1981). Sr, Cd, Mn and Co distribution coefficients in calcite as a function of calcite precipitation rate. Geochim. Cosmochim. Acta 45, 553-561. doi: 10.1016/0016-7037(81)90188-5 
Mackenzie, F. T., Bischoff, W. D., Bishop, F. C., Loijens, M., Schoonmaker, J., and Wollast, R. (1983). Magnesian calcites; low-temperature occurrence, solubility and solid-solution behavior. Rev. Mineral. Geochem. 11, 97-144.

Mann, S., Archibald, D. D., Didymus, J. M., Douglas, T., Heywood, B. R., Meldrum, F. C., et al. (1993). Crystallization at inorganic-organic interfaces: biominerals and biomimetic synthesis. Science 261, 1286-1292. doi: 10.1126/science.261. 5126.1286

Marschal, C., Garrabou, J., Harmelin, J. G., and Pichon, M. (2004). A new method for measuring growth and age in the precious red coral Corallium rubrum (L.). Coral Reefs 23, 423-432. doi: 10.1007/s00338-004-0398-6

Mavromatis, V., Gautier, Q., Bosc, O., and Schott, J. (2013). Kinetics of Mg partition and $\mathrm{Mg}$ stable isotope fractionation during its incorporation in calcite. Geochim. Cosmochim. Acta 114, 188-203. doi: 10.1016/j.gca.2013.03.024

Meibom, A., Cuif, J. P., Hillion, F. O., Constantz, B. R., Juillet-Leclerc, A., Dauphin, Y., et al. (2004). Distribution of magnesium in coral skeleton. Geophys. Res. Lett. 31:L23306.

Meibom, A., Yurimoto, H., Cuif, J. P., Domart-Coulon, I., Houlbreque, F., Constantz, B., et al. (2006). Vital effects in coral skeletal composition display strict three-dimensional control. Geophys. Res. Lett. 33:L11608.

Merlin, J. C., and Delé-Dubois, M. L. (1986). Resonance Raman characterization of polyacetylenic pigments in the calcareous skeleton. Comp. Biochem. Physiol. Part B Comp. Biochem. 84, 97-103. doi: 10.1016/0305-0491(86)90277-4

Montagna, P., McCulloch, M., Douville, E., Lopez Correa, M., Trotter, J., RodolfoMetalpa, R., et al. (2014). Li/Mg systematics in scleractinian corals: calibration of the thermometer. Geochim. Cosmochim. Acta 132, 288-310. doi: 10.1016/j. gca.2014.02.005

Mucci, A. (1986). Growth-kinetics and composition of magnesian calcite overgrowths precipitated from seawater. Quantitative influence of orthophosphate ions. Geochim. Cosmochim. Acta 50, 2255-2265. doi: 10.1016/00167037(86)90080-3

Mucci, A. (1988). Manganese uptake during calcite precipitation from seawater - conditions leading to the formation of a pseudokutnahorite. Geochim. Cosmochim. Acta 52, 1859-1868. doi: 10.1016/0016-7037(88)90009-9

Mucci, A., and Morse, J. W. (1983). The incorporation of $\mathrm{Mg}^{2+}$ and $\mathrm{Sr}^{2+}$ into calcite overgrowths - influences of growth-rate and solution composition. Geochim. Cosmochim. Acta 47, 217-233. doi: 10.1016/0016-7037(83)90135-7

Nguyen, L. T., Rahman, M. A., Maki, T., Tamenori, Y., Yoshimura, T., Suzuki, A., et al. (2014). Distribution of trace element in Japanese red coral Paracorallium japonicum by $\mu$-XRF and sulfur speciation by XANES: linkage between trace element distribution and growth ring formation. Geochim. Cosmochim. Acta 127, 1-9. doi: 10.1016/j.gca.2013.11.023

Ogilvie, M. M. (1896). Microscopic study of madreporarian types of corals. Philos. Trans. R. Soc. Lond. 187b, 83-345. doi: 10.1098/rstb.1896.0003

Okumura, M., and Kitano, Y. (1986). Coprecipitation of alkali-metal ions with calcium-carbonate. Geochim. Cosmochim. Acta 50, 49-58. doi: 10.1016/00167037(86)90047-5

Perrin, J., Rivard, C., Vielzeuf, D., Laporte, D., Fonquernie, C., Ricolleau, A., et al. (2017). The coordination of sulfur in synthetic and biogenic Mg calcites: the red coral case. Geochim. Cosmochim. Acta 197, 226-244. doi: 10.1016/j.gca.2016. 10.017

Perrin, J., Vielzeuf, D., Ricolleau, A., Dallaporta, H., Valton, S., and Floquet, N. (2015). Block-by-block and layer-by-layer growth modes in coral skeletons. Am Mineral. 100, 681-695. doi: 10.2138/am-2015-4990

Reeder, R. J., Nugent, M., Lamble, G. M., Tait, C. D., and Morris, D. E. (2000). Uranyl incorporation into calcite and aragonite: XAFS and luminescence studies. Environ. Sci. Technol. 34, 638-644. doi: 10.1021/es990981j

Rollion-Bard, C., and Blamart, D. (2015). Possible controls on Li, Na, and $\mathrm{Mg}$ incorporation into aragonite coral skeletons. Chem. Geol. 396, 98-111. doi: 10.1016/j.chemgeo.2014.12.011

Rollion-Bard, C., Cuif, J. P., and Blamart, D. (2017). Optical observations and geochemical data in deep-sea hexa- and octo-coralla specimens. Minerals 7:154. doi: 10.3390/min7090154

Rollion-Bard, C., Saulnier, S., Vigier, N., Schumacher, A., Chaussidon, M., and Lecuyer, C. (2016). Variability in magnesium, carbon and oxygen isotope compositions of brachiopod shells: implications for paleoceanographic studies. Chem. Geol. 423, 49-60. doi: 10.1016/j.chemgeo.2016.01.007

Rosenthal, Y., Boyle, E. A., and Slowey, N. (1997). Temperature control on the incorporation of magnesium, strontium, fluorine, and cadmium into benthic foraminiferal shells from Little Bahama Bank: prospects for thermocline paleoceanography. Geochim. Cosmochim. Acta 61, 3633-3643. doi: 10.1016/ S0016-7037(97)00181-6

Shaheen, M., Gagnon, J. E., Yang, Z. P., and Fryer, B. J. (2008). Evaluation of the analytical performance of femtosecond laser ablation inductively coupled plasma mass spectrometry at $785 \mathrm{~nm}$ with glass reference materials. J. Anal. At. Spectrom. 23, 1610-1621. doi: 10.1039/b809880h

Shinn, E. A. (1966). Coral growth rate, an environmental indicator. J. Paleontol. 40, 233-240.

Sinclair, D. J., Williams, B., Allard, G., Ghaleb, B., Fallon, S., Ross, S. W., et al. (2011). Reproducibility of trace element profiles in a specimen of the deepwater bamboo coral Keratoisis sp. Geochim. Cosmochim. Acta 75, 5101-5121. doi: 10.1016/j.gca.2011.05.012

Sommerdijk, N. A., and de With, G. (2008). Biomimetic $\mathrm{CaCO}_{3}$ mineralization using designer molecules and interfaces. Chem. Rev. 108, 4499-4550. doi: 10. $1021 / \mathrm{cr} 0782590$

Staudt, W. J., Reeder, R. J., and Schoonen, M. A. A. (1994). Surface structural controls on compositional zoning of $\mathrm{SO}_{4}^{2-}$ and $\mathrm{SeO}_{4}^{2-}$ in synthetic calcite single crystals. Geochim. Cosmochim. Acta 58, 2087-2098. doi: 10.1016/0016-7037(94) 90287-9

Stolarski, J. (2003). Three-dimensional micro- and nanostructural characteristics of the scleractinian coral skeleton: a biocalcification proxy. Acta Palaeontol. Pol. 48, 497-530.

Tambutté, E., Tambutté, S., Segonds, N., Zoccola, D., Venn, A., Erez, J., et al. (2012). Calcein labelling and electrophysiology: insights on coral tissue permeability and calcification. Proc. Biol. Sci. 279, 19-27. doi: 10.1098/rspb.2011. 0733

Tamenori, Y., Yoshimura, T., Luan, N. T., Hasegawa, H., Suzuki, A., Kawahata, H., et al. (2014). Identification of the chemical form of sulfur compounds in the Japanese pink coral (Corallium elatius) skeleton using $\mu$-XRF/XAS speciation mapping. J. Struct. Biol. 186, 214-223. doi: 10.1016/j.jsb.2014.04.001

Tang, J. W., Kohler, S. J., and Dietzel, M. (2008). $\mathrm{Sr}^{2+} / \mathrm{Ca}^{2+}$ and ${ }^{44} \mathrm{Ca} /{ }^{40} \mathrm{Ca}$ fractionation during inorganic calcite formation: I. Sr incorporation. Geochim. Cosmochim. Acta 72, 3718-3732. doi: 10.1016/j.gca.2008.05.031

Taubner, I., Böhm, F., Eisenhauer, A., Tambutté, E., Tambutté, S., Moldzio, S., et al. (2017). An improved approach investigating epthelial ion transport in scleractinian corals. Limnol. Oceanogr. Methods 15, 753-765. doi: 10.1002/lom3. 10194

Tesoriero, A. J., and Pankow, J. F. (1996). Solid solution partitioning of $\mathrm{Sr}^{2+}$, $\mathrm{Ba}^{2+}$, and $\mathrm{Cd}^{2+}$ to calcite. Geochim. Cosmochim. Acta 60, 1053-1063. doi: 10.1016/0016-7037(95)00449-1

Thébault, J., and Chauvaud, L. (2012). Li/Ca enrichments in great scallop shells (Pecten maximus) and their relationships with phytoplankton blooms. Palaeogeogr. Palaeoclimatol. Palaeoecol. 373, 108-122. doi: 10.1016/j.palaeo. 2011.12.014

Torrents, O., Tambutté, E., Caminiti, N., and Garrabou, J. (2008). Upper thermal thresholds of shallow vs. deep populations of the precious mediterranean red coral Corallium rubrum (L.): assessing the potential effects of warming in the NW Mediterranean. J. Exp. Mar. Biol. Ecol. 357, 7-19. doi: 10.1016/j.jembe. 2007.12.006

Trask, P. D. (1937). Inferences about the origin of oil as indicated by the composition of the organic constituents of sediments. U. S. Geol. Surv. 186, $147-157$.

Van Achterbergh, E., Ryan, C. G., Jackson, S. E., and Griffin, W. L. (2001). "Data reduction software for LA-ICP-MS," in Laser Ablation -ICP-Mass Spectrometry in the Earth Sciences: Principles and Applications, ed. P. J. Sylvester (Ottawa: Mineralogical Association of Canada Short Course Series), 239-243.

Vielzeuf, D., Garrabou, J., Baronnet, A., Grauby, O., and Marschal, C. (2008). Nano to macroscale biomineral architecture of red coral (Corallium rubrum). Am. Mineral. 93, 1799-1815. doi: 10.2138/am.2008.2923

Vielzeuf, D., Garrabou, J., Gagnon, A., Ricolleau, A., Adkins, J., Günther, D., et al. (2013). Distribution of sulphur and magnesium in the red coral. Chem. Geol. 355, 13-27. doi: 10.1016/j.chemgeo.2013.07.008

Watson, E. B. (2004). A conceptual model for near-surface kinetic controls on the trace-element and stable isotope composition of abiogenic calcite crystals. Geochim. Cosmochim. Acta 68, 1473-1488. doi: 10.1016/j.gca.2003.10.003

Weinbauer, M. G., Brandstätter, F., and Velimirov, B. (2000). On the potential use of magnesium and strontium concentrations as ecological indicators in the 
calcite skeleton of the red coral (Corallium rubrum). Mar. Biol. 137, 801-809. doi: $10.1007 / \mathrm{s} 002270000432$

Wells, J. W. (1956). "Scleractinia," in Treatise on Invertebrate Paleontology, ed. R. C. Moore (Boulder: Geological society of America), F328-F344.

Weremeichik, J. M., Gabitov, R. I., Thien, B. M. J., and Sadekov, A. (2017). The effect of growth rate on uranium partitioning between individual calcite crystals and fluid. Chem. Geol. 450, 145-153. doi: 10.1016/j.chemgeo.2016.12.026

White, A. F. (1977). Sodium and potassium coprecipitation in aragonite. Geochim. Cosmochim. Acta 41, 613-625. doi: 10.1016/0016-7037(77)90301-5

White, A. F. (1978). Sodium coprecipitation in calcite and dolomite. Chem. Geol. 23, 65-72. doi: 10.1016/0009-2541(78)90065-7

Yoshimura, T., Tamenori, Y., Suzuki, A., Kawahata, H., Iwasaki, N., Hasegawa, H., et al. (2017). Altervalent substitution of sodium for calcium in biogenic calcite and aragonite. Geochim. Cosmochim. Acta 202, 21-38. doi: 10.1016/j.gca.2016. 12.003

Yoshimura, T., Tanimizu, M., Inoue, M., Suzuki, A., Iwasaki, N., and Kawahata, H. (2011). Mg isotope fractionation in biogenic carbonates of deep-sea coral, benthic foraminifera, and hermatypic coral. Anal. Bioanal. Chem. 401, 2755-2769. doi: 10.1007/s00216-011-5264-0

Yoshimura, Y., Suzuki, A., and Iwasaki, N. (2015). Ba, B, and U element partitioning in magnesian calcite skeletons of Octocorallia corals. Biogeosci. Discuss. 12, 413-444. doi: 10.5194/bgd-12-4132015

Yu, J. M., Elderfield, H., Jin, Z. D., Tomascak, P., and Rohling, E. J. (2014). Controls on $\mathrm{Sr} / \mathrm{Ca}$ in benthic foraminifera and implications for seawater Sr/Ca during the late Pleistocene. Q. Sci. Rev. 98, 1-6. doi: 10.1016/j.quascirev.2014.05.018

Zolotoyabko, E. (2016). Anisotropic lattice distortions in biogenic minerals originating from strong atomic interactions at organic/inorganic interfaces. Adv. Mater. Interfaces 4:1600189. doi: 10.1002/admi.201600189

Conflict of Interest Statement: The authors declare that the research was conducted in the absence of any commercial or financial relationships that could be construed as a potential conflict of interest.

Copyright (c) 2018 Vielzeuf, Gagnon, Ricolleau, Devidal, Balme-Heuze, Yahiaoui, Fonquernie, Perrin, Garrabou, Montel and Floquet. This is an open-access article distributed under the terms of the Creative Commons Attribution License (CC BY). The use, distribution or reproduction in other forums is permitted, provided the original author(s) and the copyright owner(s) are credited and that the original publication in this journal is cited, in accordance with accepted academic practice. No use, distribution or reproduction is permitted which does not comply with these terms. 